\title{
WestVirginiaUniversity
}

THE RESEARCH REPOSITORY @ WVU

Graduate Theses, Dissertations, and Problem Reports

2012

\section{An in Vitro Microenvironment for Nucleus Pulposus Regeneration}

Mark S. Shoukry

West Virginia University

Follow this and additional works at: https://researchrepository.wvu.edu/etd

\section{Recommended Citation}

Shoukry, Mark S., "An in Vitro Microenvironment for Nucleus Pulposus Regeneration" (2012). Graduate Theses, Dissertations, and Problem Reports. 537.

https://researchrepository.wvu.edu/etd/537

This Thesis is protected by copyright and/or related rights. It has been brought to you by the The Research Repository @ WVU with permission from the rights-holder(s). You are free to use this Thesis in any way that is permitted by the copyright and related rights legislation that applies to your use. For other uses you must obtain permission from the rights-holder(s) directly, unless additional rights are indicated by a Creative Commons license in the record and/ or on the work itself. This Thesis has been accepted for inclusion in WVU Graduate Theses, Dissertations, and Problem Reports collection by an authorized administrator of The Research Repository @ WVU. For more information, please contact researchrepository@mail.wvu.edu. 


\title{
An in Vitro Microenvironment for Nucleus Pulposus Regeneration
}

\author{
Mark S. Shoukry \\ Thesis submitted to the \\ College of Engineering and Mineral Resources \\ at West Virginia University \\ in Partial Fulfillment of the Requirements \\ for the Degree of \\ Master of Science \\ In \\ Mechanical Engineering \\ Ming Pei, M.D., Ph.D. \\ Nianqiang Wu, PhD. \\ Jacky Prucz, Ph.D.
}

Department of Mechanical Engineering

Morgantown, West Virginia

2012

Keywords: decellularized extracellular matrix, in vitro microenvironment, synovium derived stem cells, nucleus pulposus cells 


\title{
ABSTRACT \\ An in Vitro Microenvironment for Nucleus Pulposus Regeneration
}

\author{
Mark S. Shoukry
}

Intervertebral disc degeneration begins early in life, increases with age, and can ultimately result in disc failure. At the center of the disc, the nucleus pulposus (NP) resides in a hypoxic environment where degeneration is thought to begin. Initially, nucleus pulposus cells (NPCs) display altered morphology and function, along with increased rates of cellular senescence and apoptosis. Though no widely accepted treatment exists, autologous NP implantation techniques have shown promise. However, the process is flawed as a result of the long in vitro expansion required to obtain sufficient numbers of cells. Prolonged expansion on plastic produces negative changes such as loss of the NP phenotype and reduced redifferentiation ability. Because cell based tissue engineering techniques require a metabolically active population of cells, stem cells have attracted attention for regenerative NP strategies due to their self-renewal ability and multipotent differentiation capacity. Specifically, synovium derived stem cells (SDSCs) have a higher chondrogenic capacity compared to stem cells derived from other tissues. Another advantage and potential use of SDSCs is that they can produce decellularized extracellular matrix (DECM); expansion of SDSCs or NPCs on this substrate can dramatically increase the rates of proliferation, delay senescence associated changes, and support chondrogenic activity upon induction. In this study, it was determined that NPCs alone and NPCs in co-culture with SDSCs can produce their own unique DECM. It was determined that DECM properties may be modulated by varying oxygen tension during DECM deposition. While the DECM deposited by NPCs along with SDSCs improved proliferation and guided SDSC differentiation towards the NP lineage, the effect was greater than NPC derived DECM and comparable to SDSC derived DECM. Normoxic conditions during DECM preparation were more beneficial to cell proliferation, but hypoxic conditions promoted differentiation towards the NP lineage. Finally, hypoxic conditions during pellet culture promoted NPC viability and redifferentiation. Low oxygen combined with DECM can facilitate cell-based NP regeneration. 



\section{Acknowledgements}

This work was only possible through the guidance and continued support of my advisor Dr. Ming Pei. He has shown endless effort and patience in helping ensure my success as a student. Successful completion of this work was also greatly supported by my family, who maintained an unwavering belief in my abilities. 


\section{Table of Contents}

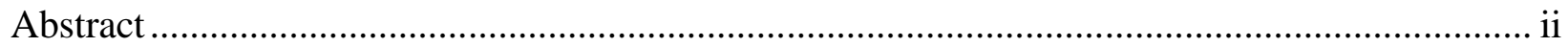

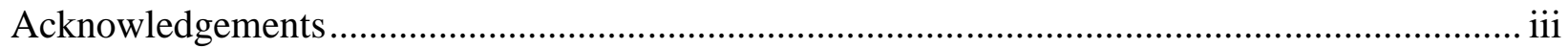

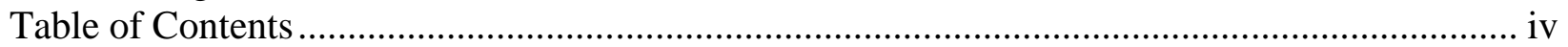

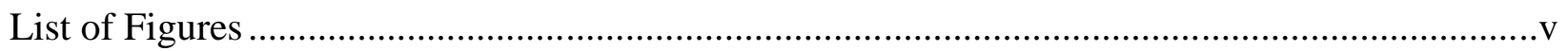

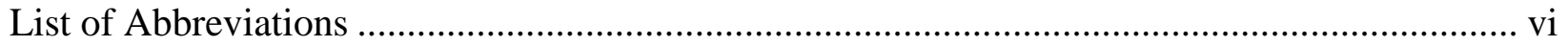

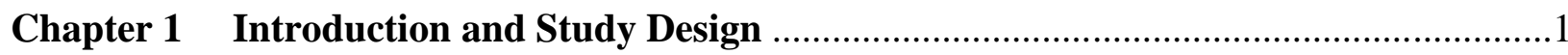

\section{Chapter 2 Intervertebral Disc Biology and Nucleus Pulposus Regeneration}

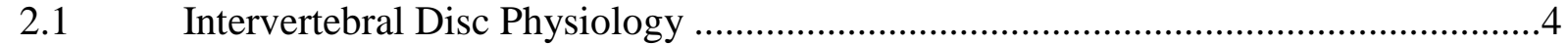

2.2 Intervertebral Disc Aging and Degeneration ................................................6

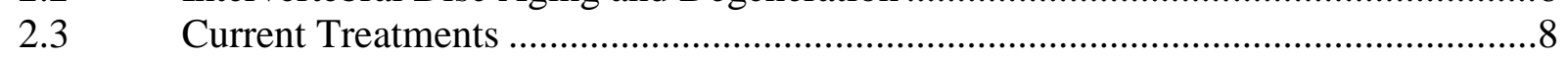

2.4 Autologous Intervertebral Disc Repair ..........................................................9

2.5 Mesenchymal Stem Cells in Nucleus Pulposus Regenerative Techniques ..............10

2.6 The Extracellular Matrix as an In Vitro Substrate ..........................................12

2.7 The Hypoxic Nucleus Pulposus Niche ........................................................... 14

\section{Chapter 3 Materials and Methods}

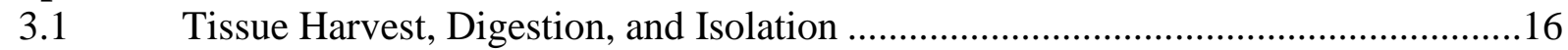

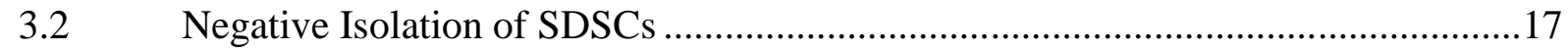

Surface Preparation ..................................................................................... 18

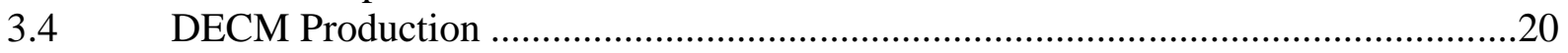

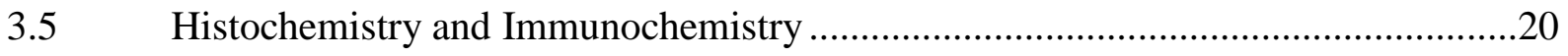

\section{Chapter 4 Results}

4.1 Experiment 1: SDSC expansion on DECM …..............................................22

Experiment 1: Histology and Immunostaining ..............................................22

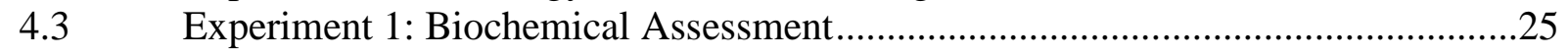

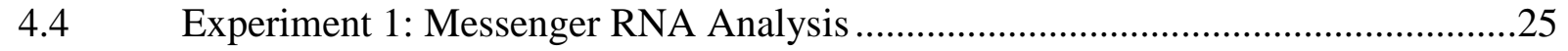

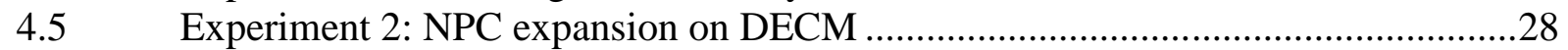

Experiment 2: Histology and Immunostaining ....................................................28

4.7 Experiment 2: Quantitative Biochemical Assessment ...........................................30

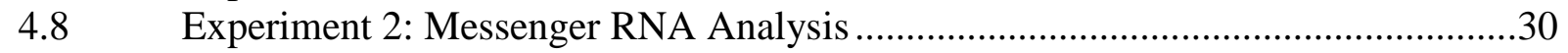

\section{Chapter 5 Discussion and Conclusion}

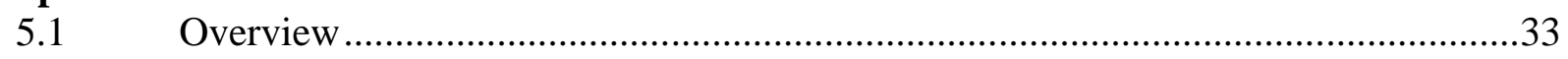

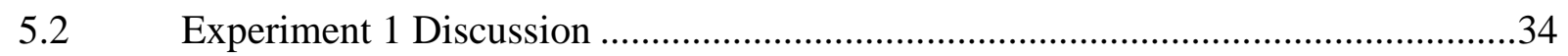

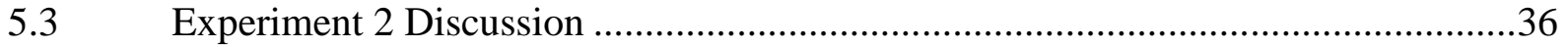

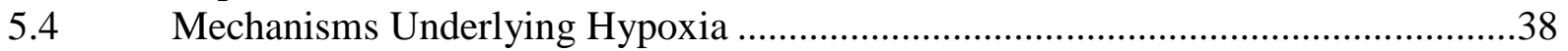

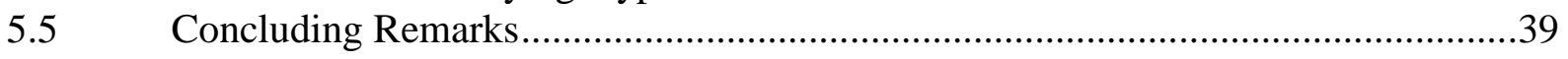

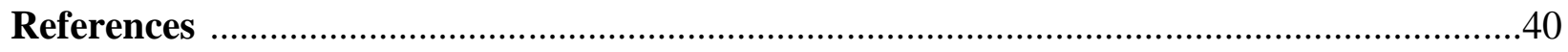

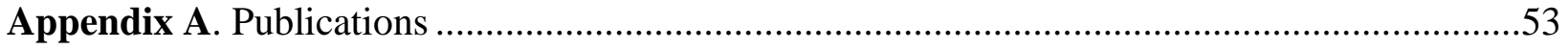




\section{List of Figures}

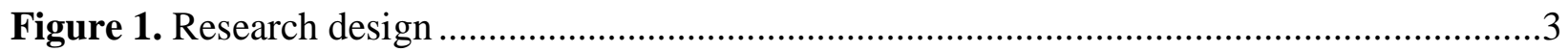

Figure 2. Intervertebral disc anatomy and relation to adjacent vertebrae ................................4

Figure 3. Healthy versus degenerate intervertebral discs ...............................................8

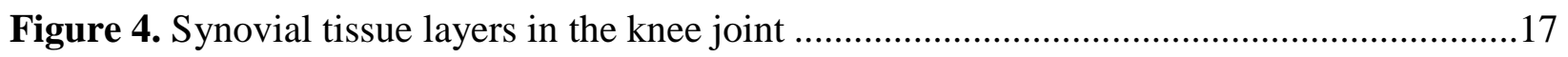

Figure 5. Experiment 1 Results: Substrate expansion, cell morphology, immunostaining .........24

Figure 6. Experiment 1 Results: Biochemical analysis and Real-time PCR ..........................27

Figure 7. Experiment 2 Results: Substrate expansion, cell morphology, immunostaining .........29

Figure 8. Experiment 2 Results: Biochemical analysis and Real-Time PCR ...........................31 


\section{List of Abbreviations}

$\begin{array}{ll}\alpha \text { Mem } & \text { alpha modified Eagle's medium } \\ \text { AF } & \text { Annulus Fibrosus } \\ \text { BMSCs } & \text { Bone Marrow Stem Cells } \\ \text { DMEM } & \text { Dulbecco's modified Eagle's medium } \\ \text { DNA } & \text { Deoxyribonucleic acid } \\ \text { ECM } & \text { Extracellular Matrix } \\ \text { DECM } & \text { Decellularized Extracellular Matrix } \\ \text { FBS } & \text { Fetal Bovine Serum } \\ \text { GAG } & \text { Glycosaminoglycan } \\ \text { MSCs } & \text { Mesenchymal Stem Cells } \\ \text { NP } & \text { Nucleus Pulposus } \\ \text { NPCs } & \text { Nucleus Pulposus Cells } \\ \text { SDSCs } & \text { Synovium Derived Stem Cells }\end{array}$




\section{Chapter 1. Introduction}

The intervertebral disk (IVD) is a composite tissue consisting of three distinct regions. Found interspaced between the bony vertebrae of the spine, the function of discs is mechanical; it transmits loads, dissipates energy, and facilitates spinal motion. The disc undergoes profound degenerative changes with age, the first of which occurs very early in life and can be observed with changes in nucleus pulposus cells (NPCs) ${ }^{13}$. Disc degeneration is a downward cascade that increases with age until almost everyone over 50 years of age is affected to some extent. Despite often times being asymptomatic ${ }^{11}$, degeneration is often thought to be the underlying cause of low back pain ${ }^{12,26,37,81}$ and can result in more serious pathologies such as sciatica, disc herniation ${ }^{153}$, and prolapse ${ }^{146}$. The high frequency and increasing severity with age result in a staggering annual cost of $£ 12$ in the United Kingdom ${ }^{89}$ and up to $\$ 200$ billion in the United States $^{68}$.

Currently, there is no way to regenerate damaged disc tissue. The first stage of treatment begins in the early phases of degeneration as pain presents. The focus is to alleviate pain and mitigate further damage. This is accomplished pharmacologically using non-steroidal antiinflammatory drugs and through other interventions such as weight loss or physical therapy. If degeneration progresses to a point where it is no longer manageable, surgery becomes the only option. Spinal fusion is considered the standard of care and aims to prevent further degeneration and eliminate pain by bridging adjacent vertebrae. However, it has been shown that pain often persists and patient quality of life does not reasonably improve. Newer options such as disc arthroplasty are still under investigation, though current results do not indicate better long term outcomes. 
Cell based tissue engineering approaches are an area of great interest for the potential to provide a method to repair damaged tissue. However, changes the NP undergoes with aging and degeneration present a number of hurdles to repair strategies. These include changes in cell phenotype, an increase in cellular senescence as well as death of the cells in the disc, and a hostile disc environment. Consequently, autologous implantation techniques using NPCs are at a disadvantage because the cell population is already negatively altered. To help address these shortcomings, stem cell supplementation has shown favorable results. Additionally, the in vitro environment represents a valuable opportunity to revitalize cells during the prolonged culture period and to prepare them for their in vivo environment.

The aim of this study is to investigate more suitable in vitro microenvironments for NP regeneration. The extracellular matrix $(\mathrm{ECM})$ is as a potent regulator of cellular behavior and provides many cues missing with plastic substrates. In addition to dramatically increasing proliferation, DECM can support chondrogenic activities upon induction ${ }^{112}$. This is in agreement with a recent hypothesis clarifying that treatment during in vitro culture is a crucial step where essential cues are given by the microenvironment to both immediately and in the future impact cell behavior ${ }^{47}$. The current standard microenvironment both lacks the appropriate cues and additionally gives abnormal signals originating from the rigid plastic substrates. Because the quality of cells used is strongly associated with outcomes in tissue engineering techniques, developing more appropriate in vitro microenvironments is an important step for improving outcomes.

The first hypothesis is that nucleus pulposus cells (NPCs) alone and a 50\%-50\% coculture of SDSCs-NPCs can deposit DECMs to facilitate SDSC proliferation and guide differentiation towards the NP lineage. Additionally, it was hypothesized that DECMs deposited 
under hypoxic versus normoxic conditions would facilitate chondrogenic differentiation in a hypoxic environment. In experiment 1 , DECM was produced by either NPCs, SDSCs, or a coculture of SDSCs \& NPCs. Each type of DECM was produced in both hypoxic (5\%) and normoxic $(21 \%)$ conditions. Subsequently, SDSCs were expanded for one passage on each type of DECM or plastic as a control, used to form pellets, and cultured in serum-free chondrogenic medium for 14 days to assess differentiation.

The second hypothesis in this study is that SDSC derived DECM deposited under hypoxia will promote NPC differentiation. In experiment 2, SDSC produced DECM under either hypoxic or normoxic conditions and NPCs were expanded for one passage on each substrate. Pellets from each group were formed and cultured in serum-free chondrogenic medium for 14 days in culture to assess differentiation. A summary of the study design is shown in figure 1 .

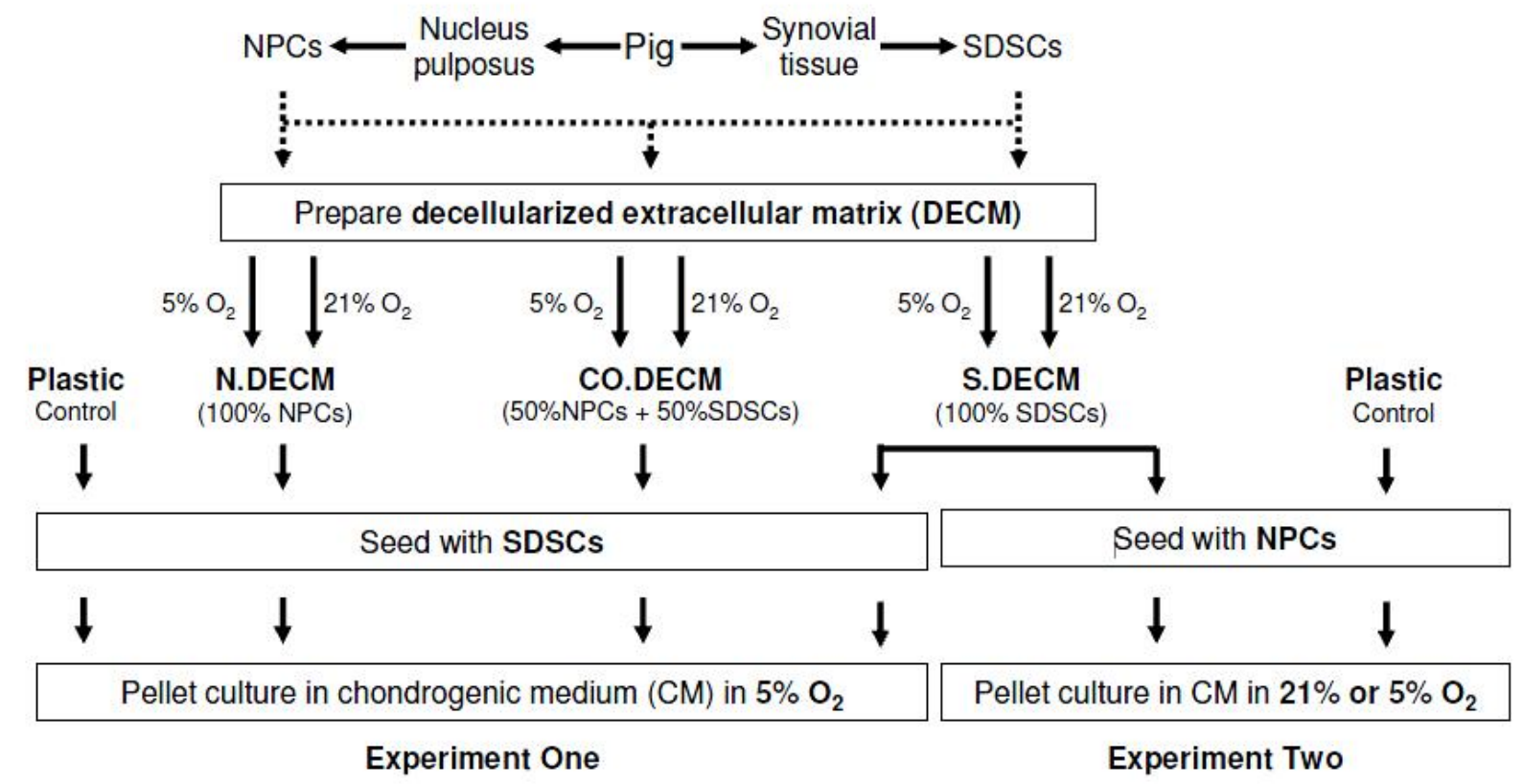

Figure 1. Research design. 


\section{Chapter 2 Intervertebral Disc Physiology}

\subsection{Intervertebral Disc Physiology}

Found between adjacent vertebral bodies in the spine, the intervertebral disc is a composite fibrocartilaginous tissue that acts to dissipate energy, support spinal loads, and facilitate spinal movement. In humans, there are a total of 24 discs that are all similar in composition and structure, but increase in size from the cervical to lumbar region ${ }^{74}$. Each disc is formed by the NP at the center, surrounding annulus fibrosus (AF), and cartilaginous endplates (CE) that form a boundary at the top and bottom between the disc and adjacent bony vertebral bodies. Nutrients to the avascular NP and inner AF are transported primarily via diffusion from vasculature originating in the vertebral bodies that terminates at the bone-disc boundary ${ }^{53,55}$.

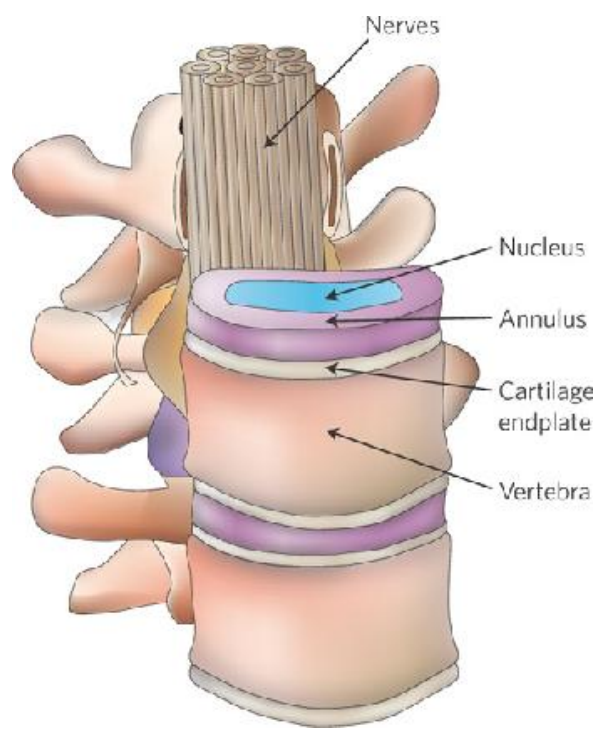

Figure 2. Intervertebral discs and relation to adjacent vertebrae ${ }^{63}$.

The AF surrounds and encloses the NP. It is composed of $70 \%$ collagen $^{33}$, and formed by 15-25 concentric lamellae consisting of bundles of obliquely oriented collagen I fibers that 
alternate direction between each layer ${ }^{83,21}$. In the outer AF, the lamellae are anchored into the adjacent vertebrae and resist excessive vertebral movement. Upon simple compression of the IVD, the AF experiences radial bulging and tensile hoop stresses due to force transferred through the NP's high osmotic pressure ${ }^{103}$. The outer annulus contains the only innervations found in the $\mathrm{IVD}^{85}$, and small vascular beds found at the dorsal and ventral AF help supply the central disc with nutrients ${ }^{49,98}$. While there is no distinct boundary between the $\mathrm{AF}$ and $\mathrm{NP}^{62}$, there is a transition zone where proteoglycan content decreases and the predominant type of collagen shifts from type II transition to type $\mathrm{I}^{33}$. Additionally, cells in the outer AF are elongated fibroblast-like cells and at the center they are more rounded ${ }^{15}$.

Responsible for over one-third the total height of the spinal column ${ }^{143}$, the NP is a highly hydrated, gelatinous structure. The NP is composed primarily of large aggregating proteoglycans in a predominantly type II collagen network, with sparsely distributed cells responsible for maintaining the ECM. The high water content has been recorded as composing up to $86 \%$ of tissue mass ${ }^{64}$, and is crucial for proper tissue function since this gives the tissue its ability to resist loading. Proteoglycans are composed of negatively charged glycosaminoglycan (GAG) chains attached to a protein core which attract water; GAG concentration is correlated to osmotic pressure and high osmotic pressure is essential for proper disc function ${ }^{115}$. Similar to cartilage, the main proteoglycan is aggrecan, which is formed by the GAGs keratin and chondroitin sulfate attached to a protein core ${ }^{139}$. Unlike similar tissues, the NP has a remarkably high ratio of proteoglycans to collagen II of 27:1 glycosaminoglycans to hydroxyproline ${ }^{96}$. Though there are other components present, they are only in small quantities. These include various other collagens including types III, V, VI, IX, X, XI, XII, and $\mathrm{XIV}^{127}$ as well as other small proteoglycans including lumican, biglycan, decorin, and fibromodulin ${ }^{87}$. Additionally, there is a 
small amount of other glycoproteins including fibronectin and amyloid. While their role is not well understood, the minor collagens may mediate collagen type I and II fibrillogenesis ${ }^{127}$ in addition to interactions between collagen fibrils and proteoglycans ${ }^{97}$. The adult disc is populated and maintained by a low density (around 4,000 cells $/ \mathrm{mm}^{3}$ ) of cells referred to as chondrocytelike $^{84}$ or Nucleus Pulposus cells (NPCs).

\subsection{Intervertebral Disc Aging and Degeneration}

It is currently thought that the degenerative process is a pathological case of maturation where normal aging associated changes take place at an accelerated rate ${ }^{1,77}$. With both aging and degeneration, the disc undergoes many changes in matrix structure and composition as well as in the resident population of cells. Because of the complex mechanical interactions through which force is transmitted between tissues in the disc, an initial disturbance in disc function trigger a downward spiral that may culminate in total disc failure. Since these changes originate in the cell population of the NP, the embryological origins and alterations from development to degeneration can provide insight about which factors are important in an NP-specific culture environment.

During development, the notochord gives rise to the immature NP which remains populated by large, vacuolated notochordal cells ${ }^{142}$. It was initially thought that this population of active cells disappeared or only remained at undetectable levels by the end of the first decade of life ${ }^{108}$. However, recent evidence suggests that while changes in the population occur through life, both populations are present well into adulthood ${ }^{150}$. The alterations in phenotype during adolescence and adulthood have been implicated as a key instigator in the degenerative process $^{16}$, in part because notochordal cells are capable of higher rates of proteoglycans synthesis $^{20}$. Additionally, the first signs of degeneration can be detected around the same time as 
the identifiable variations in NPCs, supporting the current thought that degeneration originates in the $\mathrm{NP}^{13}$. Though not fully understood, the disappearance of the original embryonically derived notochordal cell phenotype may occur through autocrine or paracrine induced Fas-mediated apoptosis $^{70}$. The contribution of programmed cell death in degeneration is the result of numerous signal transduction pathways triggered through many different stimuli ${ }^{156}$.

The in vivo disc microenvironment is considered inhospitable due to the lack of direct vasculature. The small capillary beds that originate in the vertebral bodies and extend superficially over the endplates ${ }^{55,61}$ are the predominant source of nutrients and oxygen, which must diffuse through the endplate before reaching the $\mathrm{NP}^{105}$. The only other vasculature found is at the dorsal and ventral annulus regions, but it never extends to the nucleus pulposus ${ }^{49,} 98$. Consequently, even in healthy disks, there are large gradients in nutrient concentration as a result of higher rates of consumption versus diffusion from surrounding tissues ${ }^{29,}{ }^{133}$. One major problem with aging is calcification of the endplates, which places additional hurdle diffusive transport $^{104}$. The decrease in capillary buds is correlated to proteoglycan content, age, and degeneration grade ${ }^{9}$. Finite element studies on solute transport in the disc suggest that neither elastic modulus nor proteoglycan concentration greatly influence solute distribution, but endplate properties including porosity, diffusion coefficient, and diffusion area are important ${ }^{82}$. Therefore, it may be important for cell based tissue engineering strategies to be performed before endplate calcification to optimize outcomes. The consequences of ECM degradation ${ }^{6,7,141}$ include fibrosis of the $\mathrm{NP}^{65}$ and disorganization of annular lamellae ${ }^{80}$. 


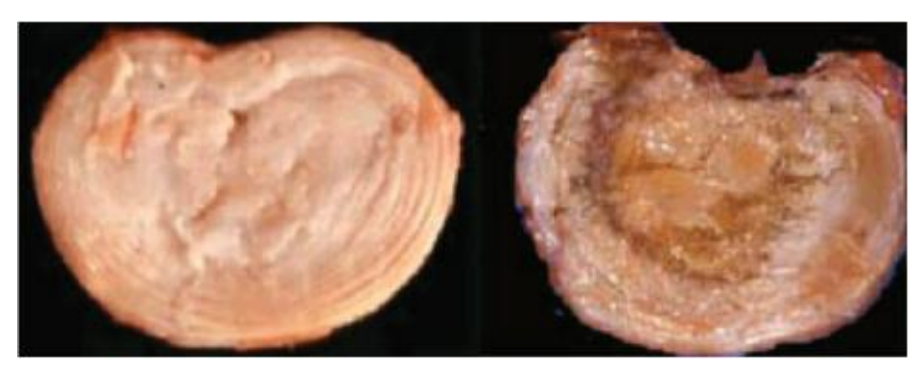

Figure 3. Healthy versus degenerate intervertebral discs ${ }^{153}$.

Another important change is reduced proliferation rates in cells harvested from aged or degenerate discs ${ }^{52}$. Increased rates of markers associated with replicative senescence ${ }^{18}$ in NPCs include senescence associated $\beta$-galactosidase biomarker and decreased mean telomere length ${ }^{51}$, ${ }^{126}$. Cells from degenerate discs also express various matrix degrading enzymes, a metabolic change also characteristic of senescent cells ${ }^{28,78,151}$.

\subsection{Current Treatment}

Because many cases of IVD degeneration are asymptomatic despite some degree of degeneration, conservative treatments to address symptoms are first used. These include medication, physical therapy, and exercise. Should conservative treatment fails and symptoms persist, surgical intervention becomes the only option. Spinal fusion is a widely performed procedure that involves using an autograft to link adjacent vertebrae and consequently stabilize the disk with the goal of eliminating pain at the cost of motion. Though it has long been the standard treatment, its efficacy in treating discogenic low back pain has been debated and results conflicting $^{38,41,91}$. Total disc replacement is a newer procedure for which a number of implants have been developed. While this procedure has shown promise, evidence regarding long term safety and efficacy versus fusion in degenerative discs is still lacking; this procedure is generally limited to scientific studies ${ }^{36,145}$. Minimally invasive NP replacement is another new technique 
employing synthetic biomaterials that has shown some potential, but investigations are still underway $^{30}$. Specifically, one promising option by Klara et al. found the device to be effective, but $38 \%$ of patients required additional surgery due to device migration ${ }^{72}$. As a consequence of their shortcomings and general lack of efficacy, biological therapeutic techniques aiming to restore damaged disc tissue is a topic of great interest and promise ${ }^{131}$ as either a standalone treatment or to supplement existing surgical procedures.

\subsection{Autologous Intervertebral Disc Repair}

First investigated in $1968^{25}$, autologous chondrocyte implantation for cartilage defect repair displayed positive results that were translated to clinical investigation in $1994^{14}$. A recent analysis of long-term (6-10 years) outcomes indicated sustained improvement in $69 \%$ of patients $^{93}$. Due to similarities between the NP and cartilage, investigators later began studying autologous cell implantation techniques for IVD regeneration. One key factor in determining therapeutic outcome is the source of cells, which can be problematic since some harvest procedures may cause further damage, and using cells from a damaged tissue is not ideal. Cell types investigated for autologous NP implantation include chondrocytes from articular cartilage $^{46,155}, \mathrm{NPCs}^{39,101}$, and adult stem cells.

One of the major drawbacks of using autologous NPCs is that cells derived from the degenerate disc are not as suited for rebuilding tissue as healthy counterparts, even after expanded to large numbers. With degeneratation, cells undergo negative morphological, phenotypical, and metabolic alterations. These include increased numbers of cells in the process of dying or already dead through either necrosis or apoptosis, as well as a higher frequency of

cells displaying the senescent phenotype ${ }^{13,50,126,142}$. These cells display altered genotypic and 
phenotypic behavior in vitro, such as lower gene expression of critical matrix proteins and increased catabolic matrix enzyme expression ${ }^{66}$. Suspected shortcomings of degenerate cells for in vivo repair were verified when Hegewald et al. used cells from patients with herniated discs to form $3 \mathrm{D}$ constructs and found significant signs of dedifferentiation that increased further with in vitro expansion and a decreased ability to redifferentiate ${ }^{57}$. Therefore, for the patient population demonstrating the greatest need, autologous NPCs may not be a viable option.

\subsection{Mesenchymal stem cells in Nucleus Pulposus Regenerative Techniques}

Mesenchymal stem cells possess the capacity to differentiate into various cell types capable of creating a number of tissues ${ }^{19}$. While a variety of different cell sources have been proposed to overcome the challenges of using degenerate NP cells, MSCs are thought to offer the greatest potential for successful clinical application ${ }^{121}$. Most notably, MSCs were recently successfully identified in degenerate NP and possess a capacity to differentiate towards an NPlike lineage ${ }^{121}$. Stem cells isolated from the disc display morphological, immunophenotypical, and differentiation criteria ${ }^{10,124}$ typical of stem cells. However, while NP derived MSCs may play a role in regenerative strategies in the future, their extremely limited availability and extensive harvesting procedures make them a poor option for regenerative techniques. Their presence does however help support the trend to use cocultures of MSCs and NPCs as a method to specify MSC lineage in a population of MSCs isolated from various adult tissues.

Stem cells derived from the bone marrow are the most frequently used for stem cell based NP regeneration. The newest data supports their use in a coculture environment; stem cells exert a positive effect on overall proteoglycan production, and NPCs may help guide MSCs towards the NP lineage. When cultured with bone marrow derived stem cells (BMSCs), coculture with 
direct cell-to-cell contact as observed in most in vivo stem cell niches enhances the properties of human derived BMSCs and NPCs ${ }^{149}$. Studies on cells of the NP suggests there may be a three cell types present: notochordal cells, chondrocyte-like cells, and an NP derived stem cell population. While their interactions are still poorly understood, in vitro experiments using notochordal cell conditioned medium (NCCM) identified the precursor of the multifunctional connective tissue growth factor; an increase in proteoglycan expression in NPCs occurs when treated with NCCM. Conditioned medium additionally can support in vitro MSC differentiation towards the NP lineage ${ }^{117}$. This is thought to occur due to the secretion of growth factors and soluble proteins which promote anabolic metabolism in cells as opposed to the catabolic behavior observed during degeneration ${ }^{86}$. This evidence may additionally suggest that notochordal cells act as regulators of NPCs.

One frequently used technique to guide MSC differentiation to the NPC lineage is through coculture. Recently, Allon et al. developed a novel bilaminar coculture pellet system that more closely resembles the embryonic development of the $\operatorname{IVD}^{4,5}$. When tested in vivo, implanted bilaminar coculture cells improved both disc height and grade over time ${ }^{4}$. Their most recent study simulating the degenerate disc environment verified the benefits of bilaminar coculture, but did not compare the results to traditional coculture to determine whether the bilaminar system is superior ${ }^{5}$. The BMSC-NPC coculture system has also been verified by others to support differentiation toward an NP-like lineage $\mathrm{e}^{102,140}$.

Though BMSCs remain the most widely investigated type of adult stem cell for NP regeneration, they may not represent the ideal source. Synovium derived stem cells (SDSCs) have been proposed as another important candidate for NP-regeneration. The argument for SDSCs in NP tissue engineering is similar to that for their successful use in cartilage tissue 
engineering; both the synovium and cartilage originate from a common pool of precursor cells ${ }^{106}$ and express similar link protein ${ }^{35}$ and GAG profiles ${ }^{54}$. Additionally, some comparative studies to BMSCs have also shown SDSCs to possess a higher capacity towards chondrogenesis ${ }^{130,136,154 .}$ All of these traits suggest they may better be suited to rebuild the degenerate cartilage-like NP.

The coculture technique has also been successfully demonstrated in SDSC-NP cultures that produce high aggrecan and collagen type II tissue similar to that of found in the $\mathrm{NP}^{24}$. During culture, human serum supplemented SDSCs also expand more rapidly than BMSCs ${ }^{100}$, suggesting they may offer advantages over BMSCs for regeneration. Similar results to in vivo BMSC studies were achieved when SDSCs were implanted in degenerate discs and found to increase type II collagen production and suppress matrix degrading enzymes implicated in the degenerative process ${ }^{92}$. The inhibition of catabolic enzymes and cytokines may provide a good therapeutic target because of their association with disc degeneration ${ }^{151}$. Thus, SDSCs may offer another good supplement of regenerative NP strategies.

\subsection{The Extracellular Matrix as an In Vitro Substrate}

Both in vitro and in vivo, the extracellular matrix to which cells are attached is a major component of the microenvironment that provides signals to determine cell behavior through both physical and biochemical interactions. The extracellular matrix is a dynamic structure that remains active throughout life, facilitating the transmission of physiological signals though it's mechanical structure and chemical composition ${ }^{75}$. A primary method of cell-ECM communications occurs via integrins, a family of transmembrane proteins operating as cell surface receptors which connect the cytoskeleton to the surrounding extracellular matrix ${ }^{40}$. Functioning as heterodimers, integrins are composed of an $\alpha$ and a $\beta$ subunit; each unique 
subunit combination determines binding to specific certain ECM components. Importantly, integrin expression is dependant on the cell type and can serve to help identify downstream cellular responses from cell-matrix or cell-cell interactions.

Work by Nettles et al. initially identified functional integrin subunits in NP and AF, and found discrepancies in the prevalence of subunits in each ${ }^{99}$. The primary difference was higher expression of the $\alpha 6$ and $\beta 4$ subunits in the $\mathrm{NP}^{99}$. The $\alpha 6$ subunit exists in two forms, and has been suggested as a requirement for MSC chondrogenic differentiation ${ }^{132}$. Using flow cytometry to quantify integrin expression levels first upon isolation and subsequently after monolayer culture, it was found that the $\alpha 6$ expression was significantly higher in NPCs and that type II collagen adhesion occurred through the $\alpha 1 \beta 1$ receptor, but type I collagen adhesion was only partially mediated through this receptor. Finally, fibronectin attachment was found to occur through the $\alpha 5 \beta 1$ integrin $^{42}$.

In combination with $\beta 1$ or $\beta 4$, the $\alpha 6$ subunit is a primary mediator of cellular adhesion to the extracellular matrix protein laminin, a heterotrimeric protein composed of individual $\alpha, \beta$, and $\gamma$ chains. Currently, at least 15 identified isoforms have been identified which are expressed differently in various tissues ${ }^{27}, 90$. In NPCs, higher expression of the $\alpha 5$ laminin chain, the laminin receptors integrin subunits $\alpha 3, \alpha 6$, and $\beta 4$ along with CD239, and CD151 were found compared to cells from the $\mathrm{AF}^{23}$; these suggest that Laminin may be a good match for NPCs. Gilchrist et al. examined cell-matrix interactions and found faster cell spreading and higher risistance to detachment on laminin isoforms LM-511 and LM-332, in contrast to LM-111, fibronectin, and collagen $\mathrm{II}^{44}$. Substrates coated with laminin softer than $720 \mathrm{~Pa}$ were also found to promote in vitro proteoglycan production, cell-cell interactions, and the NP morphology ${ }^{43}$. Unsurprisingly, the notochord from which the NP is believed to drive is a laminin rich 
structure $^{120}$ and laminin coatings may one alternative to plastic substrates and promote the NP lineage. However, these single component ECMs may not capture the needed complexity of in vivo ECMs for regulating cell behavior. A promising alternative method that has been shown to produce very strong positive changes in proliferation and differentiation for cartilage tissue engineering utilizes cell produced ECM.

\subsection{Hypoxia in the disc}

The avascular $\mathrm{NP}^{129}$ relies on diffusion through long distances for nutrient transport; cells must therefore be adapted for a hypoxic and nutrient deprived environment. Blood vessels from the vertebral bodies extend across the superficial regions of endplates ${ }^{55}$. Additionally, small, sparsely distributed vascular beds extend to the dorsal and ventral surfaces of the annulus fibrosus but never penetrate the NP, even after major disc disruption ${ }^{49,98}$. In agreement, oxygen concentrations are lowest and lactate concentrations highest in the $\mathrm{NP}^{8}$. The lack of vasculature causes an accumulation of anerobic metabolism byproducts which produce a low $\mathrm{pH}^{144}$ and high osmolarity $^{71}$. The NP can therefore be concluded to exist in a hypoxic niche where cells express a unique phenotype that differentiates them from those of surrounding tissues ${ }^{118}$; this phenotype also facilitates survival and function in a hypoxic environment. In the experiments performed for this study, we investigate the interplay between DECM and the hypoxic environment on proliferation and differentiation toward the NP lineage. 


\section{Chapter 3. Materials and Methods}

\subsection{Isolation and culture of SDSCs and NPCs}

Two three month old pigs were obtained from a local slaughterhouse and sacrificed for synovial tissue from both knees and NP from each IVD between the lumbar vertebrae.

\section{Synovial tissue digestion}

Random tissue samples were harvested aseptically from the intimal layer of synovial tissue from the knees of each of the three month old pigs and immediately placed in complete medium at $4{ }^{\circ} \mathrm{C}$. The tissue was finely minced with scalpels and digested on an $\mathrm{x}-\mathrm{y}-\mathrm{z}$ shaker (Clay Adams Nutator, BD) initially in a solution of phosphate buffered saline (PBS) from Invitrogen containing $0.1 \%$ trypsin (Roche) for 30 minutes at $37^{\circ} \mathrm{C}$, and subsequently in a $0.1 \%$ collagenase P (Roche) solution with $10 \mathrm{U} / \mathrm{mL}$ hyaluronidase (Sigma) in DMEM/10\% FBS, 100 $\mathrm{U} / \mathrm{ml}$ penicillin, $100 \mathrm{~g} / \mathrm{ml}$ streptomycin for 2 hours. To eliminate any remaining undigested tissue, the suspension was filtered through a 70 m nylon filter. Cells were plated in complete medium [ $\alpha$ MEM containing 10\% fetal bovine serum (FBS), $100 \mathrm{U} / \mathrm{ML}$ penicllin, $100 \mathrm{~g} / \mathrm{mL}$ streptomycin, and $0.25 \mathrm{~g} / \mathrm{mL}$ fungizone (Invitrogen)]. Medium changes were performed every two days to remove nonadherent cells. 


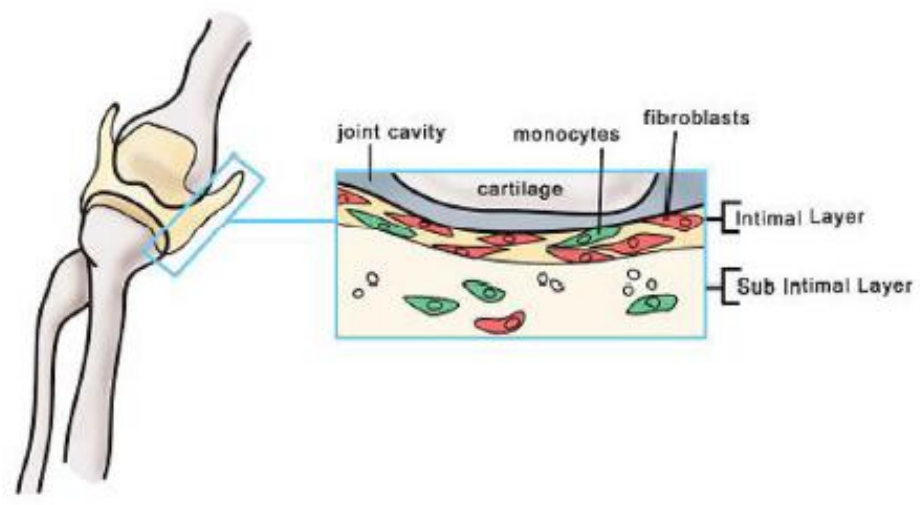

Figure 4. Synovial tissue layers in the knee joint ${ }^{110}$

\section{Nucleus Pulposus digestion and NP isolation}

The harvested NP tissue was digested using a solution of $0.1 \%$ collagenase A (Sigma, St. Lous, MO) and $10 \mathrm{U} / \mathrm{mL}$ hyaluronidase (Sigma) in DMEM containing 10\% FBS for 4 hours at $37^{\circ} \mathrm{C}$. Any remaining undigested tissue was removed by filtering through a 70 m nylon filter. Cells were plated in complete medium and medium changes were performed every two days to remove nonadherent cells.

\subsection{Negative Isolation and of SDSCS}

The SDSCs were negatively isolated from primary cultures of adherent synovial cells composed of both macrophages and fibroblasts ${ }^{109,113,157}$ by first detaching cells by trypsinization (0.25\% trypsin/0.2\% EDTA) for no longer than 2 minutes. After washing, cells were suspended in PBS $/ 2 \%$ FBS $\left(10^{7} / \mathrm{ml}\right)$ and incubated with $5 \times 10^{7} / \mathrm{mL}$ Dynabeads ${ }^{\circledR}$ M-450 CD14 containing a monoclonal antibody specific for macrophages (Dynal Biotech, Oslo, Norway) at $4^{\circ} \mathrm{C}$ for $1 \mathrm{~h}$. The conjugated cells and unbound Dynabeads ${ }^{\circledR}$ were collected using the Dynal Magnetic Particle Concentrator $^{\circledR}$ (Dynal Biotech, Oslo, Norway). The now depleted supernatant with synovial fibroblasts (referred to as $\operatorname{SDSCs}^{8}$ ) was saved for further passaging. 


\subsection{Gelatin Surface Preparation}

This procedure was performed for all DECM groups before seeding cells. Plastic flasks were first coated with $0.2 \%$ gelatin (Sigma, St. Louis, MO) and placed in $37^{\circ} \mathrm{C}$ incubators for 1 hour. The gelatin solution was aspired and the surface washed with PBS. The flasks were then coated with a $1 \%$ glutaraldehyde solution and allowed to rest at room temperature for 30 minutes. Next, flasks were washed 3 times for 5 minutes each, coated with $1 \mathrm{M}$ ethanolamine solution, and allowed to rest at $37^{\circ} \mathrm{C}$ for 30 minutes. The flasks were again washed 3 times for one hour.

\subsection{DECM Production}

Passage 3 SDSCs for S.DECM or passage 1 NPCs for N.DECM were plated at 6,000 cells $/ \mathrm{cm}^{2}$. Co-culture ECM was produced by seeding 3,000 cells $/ \mathrm{cm}^{2}$ SDSCs with 3,000 cells $/ \mathrm{cm}^{2}$ NPCs. Until reaching $90 \%$ confluence, all groups were placed in $21 \% \mathrm{O}_{2}$ incubators. Medium changes were performed every two days (complete medium). Upon reaching 90\% confluence, the complete medium was supplemented with $50 \mathrm{M}$ of L-ascorbic acid (Wake Chemicals USA Inc., Richmond, VA) and one group was left in the $21 \% \mathrm{O}_{2}$ incubator while another was transferred into a 5\% oxygen (hypoxia) incubator for 8 days during DECM deposition. Finally, each group was incubated with $0.5 \%$ Triton X-100 containing $20 \mathrm{mM}$ ammonium hydroxide at $37^{\circ} \mathrm{C}$ (in the same oxygen concentration incubator as during ECM production) for an average of 4 minutes to remove cells. The DECMs in each group were stored at $4^{\circ} \mathrm{C}$ in PBS containing $100 \mathrm{u} / \mathrm{mL}$ penicillin, $100 \mathrm{~g} / \mathrm{mL}$ streptomycin and $0.25 \mathrm{~g} / \mathrm{mL}$ fungizone. 


\section{Experiment 1 Part 1: SDSCs passaged on SDSC, NPC, or SDSC-NPC DECM in hypoxia}

In this experiment, there were a total of 7 experimental groups. Passage 3 SDSCs were seeded at a density of 3,000 cells $/ \mathrm{cm}^{2}$ for one passage onto N.DECM, Co.DECM, or S.DECM, at either $21 \%$ or $5 \%$ oxygen. After 1 passage, cell counting was performed and pellets were created. Following overnight incubation, pellets were treated with condrogenic medium and maintained at $5 \%$ oxygen for the remaining 14 days in an incubator.

\section{Experiment 2 Part 1: NPCs cultured on SDSC-ECM deposited under hypoxia}

In this experiment, there were a total of 6 experimental groups. Passage 1 NPCs were seeded onto S.DECM deposited at either normal $\left(21 \% \mathrm{O}_{2}\right)$ or hypoxic $\left(5 \% \mathrm{O}_{2}\right)$ conditions. Subsequently, passage 1 NPCs were seeded at a density of 3,000 cells $/ \mathrm{cm}^{2}$ for one passage on each type of DECM. Finally, after pellets were created and following overnight incubation were treated with chondrogenic medium and maintained at either $21 \%$ or $5 \%$ oxygen for the remaining 14 days in an incubator.

\section{Experiments 1\&2 Part 2: Pellet Culture and Chondrogenic Differentiation}

After in vitro expansion, $0.3 \times 10^{6}$ cells from each pretreatment were centrifuged at $500 \mathrm{~g}$ for $7 \mathrm{~min}$ in $15-\mathrm{mL}$ polypropylene tubes to form cell pellets. Following overnight incubation, pellets were cultured in serum-free chondrogenic medium containing high-glucose DMEM, 40 $\mathrm{g} / \mathrm{mL}$ praline, $100 \mathrm{nM}$ dexamethasone, $100 \mathrm{U} / \mathrm{mL}$ penicillin, $100 \mathrm{~g} / \mathrm{mL}$ streptomycin, $0.1 \mathrm{mM}$ ascorbic acid-2-phosphate, and $1 \mathrm{x} \mathrm{ITS}^{\mathrm{TM}}$ Premix $(6.25 \mathrm{~g} / \mathrm{mL}$ insulin, $6.25 \mathrm{~g} / \mathrm{mL}$ transferring, $6.25 \mathrm{~g} / \mathrm{mL}$ selenous acid, $5.35 \mathrm{~g} / \mathrm{mL}$ linoleic acid and $1.25 \mathrm{~g} / \mathrm{mL}$ bovine serum albumin from BD Biosciences, Bedford, MA) with supplementation of $10 \mathrm{ng} / \mathrm{mL}$ transforming growth factor 
beta3 (TGF- $\beta 3$, PeproTech Inc., Rocky Hill, NJ) for 14 days. Pellets were collected at days 0, 7, and 14 for chondrogenic evaluation.

\subsection{Histochemistry and immunochemistry}

Randomly selected pellets $(n=3)$ from each data point were first fixed in a $4 \%$ paraformaldehyde solution at $4^{\circ} \mathrm{C}$ overnight. Samples were embedded in paraffin and $5 \mathrm{~m}$ sections were cut. Successive segments were stained with safranin O/fast green for sulfated GAG and immunostained with monoclonal antibodies against collagen I (Sigma) and collagen II [II-II6B3, Developmental Studies Hybridoma Bank (DSHB) Iowa City, IA], collagen I (Sigma). Immunohistochemical sections were hydrated, treated with $1 \%$ hydrogen peroxide to inhibit endogenous peroxidase, and incubated first for 30 minutes with $2 \mathrm{mg} / \mathrm{mL}$ testicular hyaluronidase in phosphate-buffered saline $(\mathrm{pH} 5)$ at $37^{\circ} \mathrm{C}$, another 30 minutes with $1.5 \%$ normal horse serum, and finally overnight at $4^{\circ} \mathrm{C}$ with the primary antibody. A secondary antibody of biotinylated horse anti-mouse $\operatorname{IgG}$ (Vector, Burlingame, CA) was incubated on sections for 30 minutes). Immunoactivity was detected using the Vectastain $A B C$ reagent (Vectastain $A B C$, Burlingame, CA) with 3-3'-diaminobenzidine (DAB, 0.05\%) and hydrogen peroxide $\left(\mathrm{H}_{2} \mathrm{O}_{2}\right.$, $0.015 \%)$ as a substrate with hematoxylin (Vector) as a counterstain.

\subsection{Biochemical analysis for DNA and GAG content}

The pellets $(\mathrm{n}=4)$ were digested for 4 hours at $60^{\circ} \mathrm{C}$ with $125 \mathrm{~g} / \mathrm{mL}$ papain in PBE buffer (100 mM phosphate, $10 \mathrm{mM}$ EDTA, pH 6.5) containing $10 \mathrm{mM}$ cysteine. Each sample was digested using $100 \mathrm{~L}$ of enzyme. Quantification of cell density was accomplished by measuring the amount of DNA in the papain digestion using a QuantiT ${ }^{\mathrm{TM}}$ PicoGreen $^{\circledR}$ dsDNA 
assay kit (Invitrogen, Carlsbad, CA) with a CytoFluor ${ }^{\circledR}$ Series 4000 (Applied Biosystems, Foster City, CA). The GAG content was measured using dimethylmethylene blue dye and a Spectronic $^{\mathrm{TM}}$ BioMate $^{\mathrm{TM}} 3$ Spectrophotometer (Thermo Scientific, Milford, MA) with bovine chondroitin sulfate from Sigma as a standard.

\subsection{TaqMan $^{\circledR}$ Quantitative PCR}

The total RNA was extracted from samples $(n=4)$ using an RNase-free pestle in TRIzol ${ }^{\circledR}$ (Invitrogen). One $\mu \mathrm{g}$ of mRNA was used for reverse transcriptase (RT) with a High-Capacity cDNA Archive Kit at $37^{\circ} \mathrm{C}$ for 120 min as recommended by the manufacturer (Applied Biosystems). Chondrogenic marker genes [collagen II (Col II) (Assay ID: AIJ9V6I)] and hypertrophic genes [collagen $X(\mathrm{Col} \mathrm{X})$ (Assay ID: AI382VX) and alkaline phosphatase (ALP) (Assay ID: AI1Q8RQ)] were customized by Applied Biosystems as part of the Custom Taqman ${ }^{\circledR}$ Gene Expression Assays. Eukaryotic 18S RNA (Assay ID: HS99999901_s1 ABI) was carried out as the endogenous control gene. Real-time PCR was performed with the iCycler $\mathrm{iQ}^{\mathrm{TM}}$ Multi Color RT-PCR Detection System and calculated by computer software (Perkin-Elmer, Waltham, MA). Relative transcript levels were calculated as $\chi=2^{-} \quad$ Ct in which $\mathrm{Ct}=\mathrm{E}-\mathrm{C}, \quad \mathrm{E}=\mathrm{Ct}_{\mathrm{exp}}-\mathrm{Ct}_{18 s}$, and $\mathrm{C}=\mathrm{Ct}_{\mathrm{ct} 1}-\mathrm{Ct}_{18 \mathrm{~s}}$.

\subsection{Statistics}

The Kruskal-Wallis test was used to test for significant differences among all groups and the Mann-Whitney U test was used for pairwise comparison in biochemistry analysis and realtime PCR data. All statistical analyses were performed with SPSS 13.0 statistical software (SPSS Inc., Chicago, IL). $P$ values less than 0.05 were considered statistically significant. 


\section{Chapter 4 Results}

(Partially adapted from Pei M, Shoukry M, et al. ${ }^{114}$ )

\subsection{Experiment 1: SDSC expansion on DECM (Figure 5A \& B)}

To determine the feasibility of varying oxygen tension as a method of modulating DECM properties, S.DECM, N.DECM, and Co.DECM were prepared under either normoxic or hypoxic conditions. For one passage, SDSCs were cultured on each substrate and plastic to serve as a control. After 5 days, cell numbers were used to assess the effect of each DECM on SDSC proliferation (Figure 5A). It was found that the effect of hypoxia or normoxia produced DECM on SDSC numbers after 1 passage was not significant, but all DECMs greatly enhanced proliferation compared to plastic controls. The highest cell numbers were recorded by S.DECMs. Pronounced morphological changes in cell shape and organization were observed in DECM groups relative to plastic (Figure 5). Namely, plastic expanded cells became large and flattened while DECM expanded cells became small and spindle shaped. Additionally, cell density remained similar between days 3 and 5 on plastic while dramatic increases were observed in DECM groups. In DECM groups, cells were also observed to propagate along DECM fibers and can be seen to above and below other cells, while propagation in plastic appeared limited to the 2D substrate.

\subsection{Experiment 1: Histology and Immunostaining (Figure 5C)}

Differentiation potential was assessed after one passage on each type of DECM using pellet culture for fourteen days in serum-free chondrogenic medium supplemented with TGF- $\$ 3$. The results of staining for collagen type I, type II, and GAGs are displayed in Figure 5 below. 
After 14 days, DECM expanded SDSCs produced larger pellet sizes than plastic. In all DECM expanded groups, intense staining was observed for sulfated GAGs by both Alcian blue and Safranin O staining. Immunostaining for collagen II was stronger and more homogenous in hypoxic versus normoxic cultures, most notably in the center of pellets. Only minimal staining for collagen, either type I or II, was observed in the plastic group. Finally, immunostaining for collagen I was also stronger in DECM groups than plastic, though 5\% S.DECM appeared to have the lowest levels among DECM groups, with the exception of the 5\% Co-culture group that was similar. 


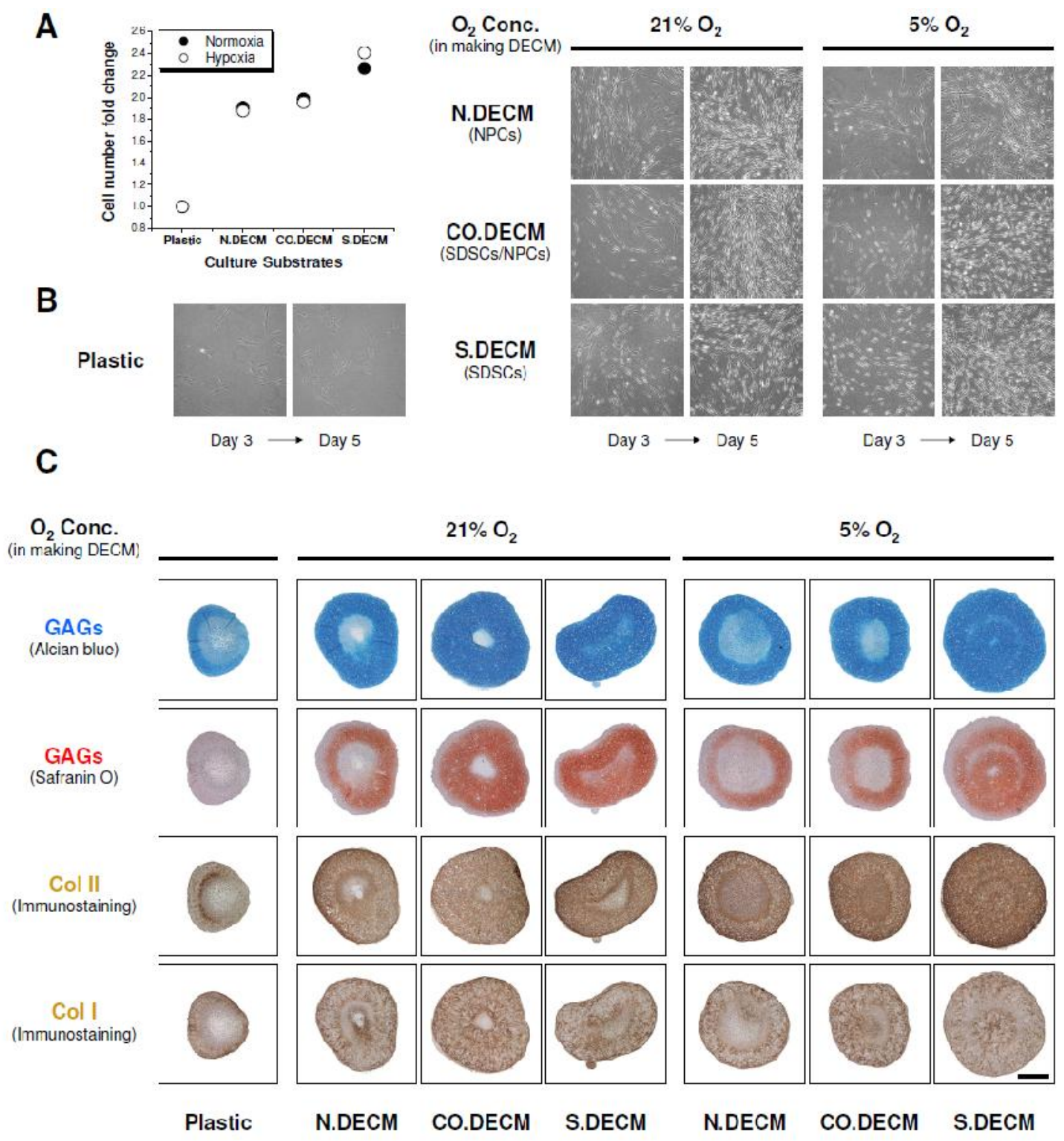

Figure 5. The proliferation rates and chondrogenic potential were improved after DECM expansion. (A) Passage 3 SDSCs were expanded on seven substrates for one passage. Cell number was quantified using a counting hemocytometer from four $175 \mathrm{~cm}^{2}$ plastic flasks in each group; (B) Cell morphology at days 3 and 5 during expansion; and (C) Expanded cells were cultured in a serum-free chondrogenic medium in a pellet system for 14 days. Alcian blue and Safranin O staining were used to detect sulfated GAGs. Immunostaining was used for collagens I and II. The scale bar is $800 \mu \mathrm{m}$. 


\subsection{Experiment 1: Biochemical Assessment (Figure 6A)}

Relative DNA contents were calculated by dividing the DNA content at a given time point (i.e. days 7 and 14) by that of day 0 to facilitate comparison between groups. At day 7 , S.DECM, CO.DECM, and plastic all remained at similar levels. Both N.DECM groups were also at a similar level, with the hypoxic the N.DECM group at a slightly (statistically significant) lower level. Ratios dropped by day 14 and any significant inter-group variance was eliminated, showing that viability was maintained well in all groups regardless of DECM pretreatment.

Relative GAG content (GAG index) was adjusted by dividing the GAG content at a time point by the DNA content at that time point, providing a comparable measure for variation in GAG content between groups after adjusting for differences in DNA content. At day 0, all groups were at a minimal level. By day 7, all DECM groups had a higher total GAG content and GAG index than the plastic control. The highest total GAG content at this time point was in the normoxic CO.ECM and S.ECM groups, but after adjusting for DNA the difference became minimal. The trend continued at day 14 where absolute GAG content was again highest in the normoxic CO.DECM and S.DECM groups, but after adjusting for DNA, variation became minimal. The plastic group remained at a very low level compared to DECM groups.

\subsection{Experiment 1: Messenger RNA Analysis (Figure 6B)}

Since the major type of collagen in the disc is type I, variability in the properties of DECMs created as a result of either the cell type that produced them or environment in which they were produced, the effect on this gene was examined. All DECM groups exhibited collagen II mRNA levels many times higher than plastic. No statistical difference was observed between 
both N.DECM, S.DECM, and CO.DECM groups. However, both hypoxic and normoxic N.DECM groups were at the lowest level among DECM groups.

The hypertrophic markers used were collagen $\mathrm{X}$ since it signifies late-stage chondrocyte hypertrophy ${ }^{119,95}$ and alkaline phosphatase for key roles in mineralization ${ }^{60,45}$. Plastic yielded significantly higher mRNA levels of collagen $\mathrm{X}$ than either of the CO.DECM and S.DECM groups, but similar levels to both N.DECM groups. In contrast, plastic produced the lowest ALP mRNA levels. Among DECM groups, the lowest significant levels were in S.DECMs and the highest level was found in the normoxic N.DECM group. 

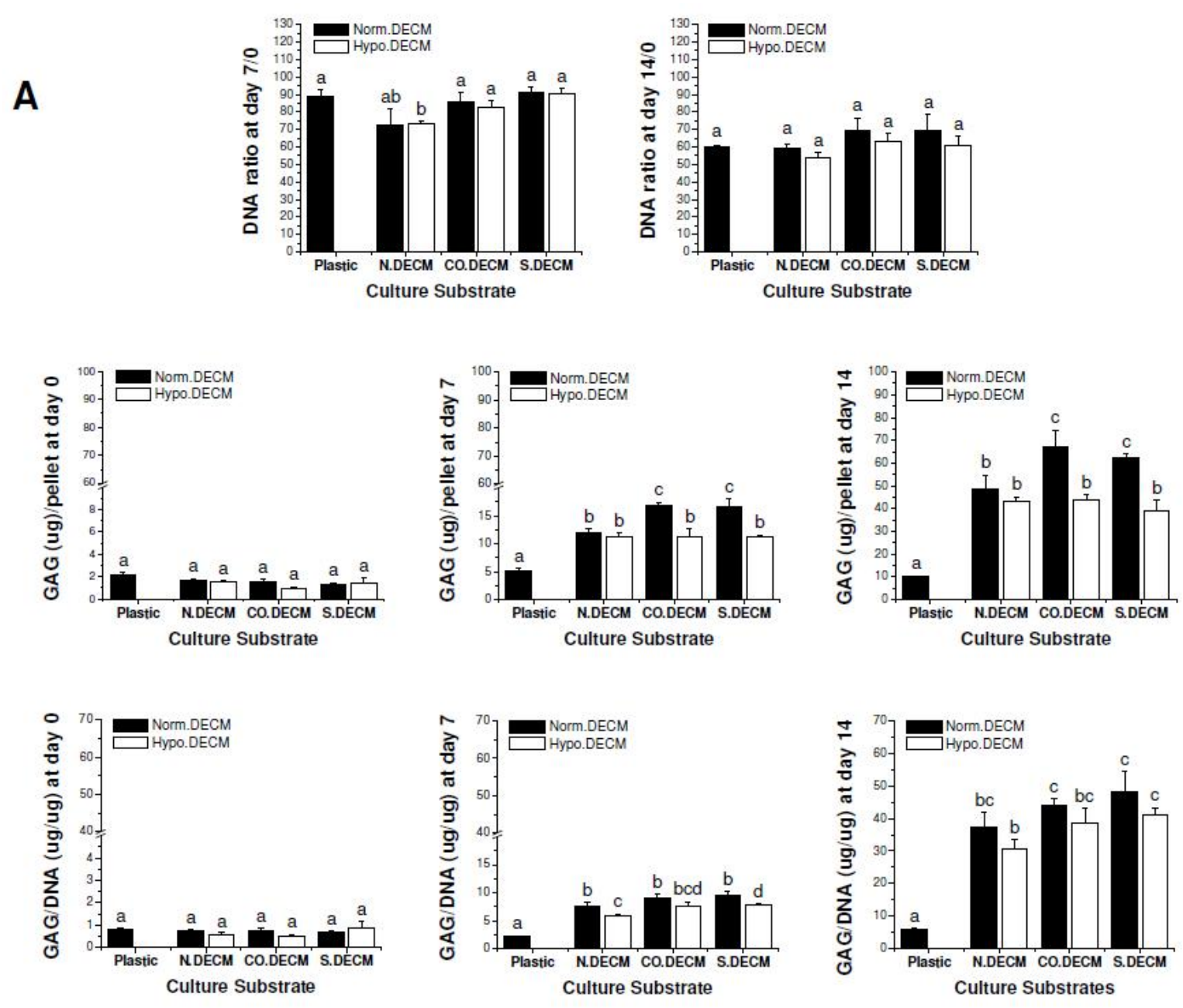

B
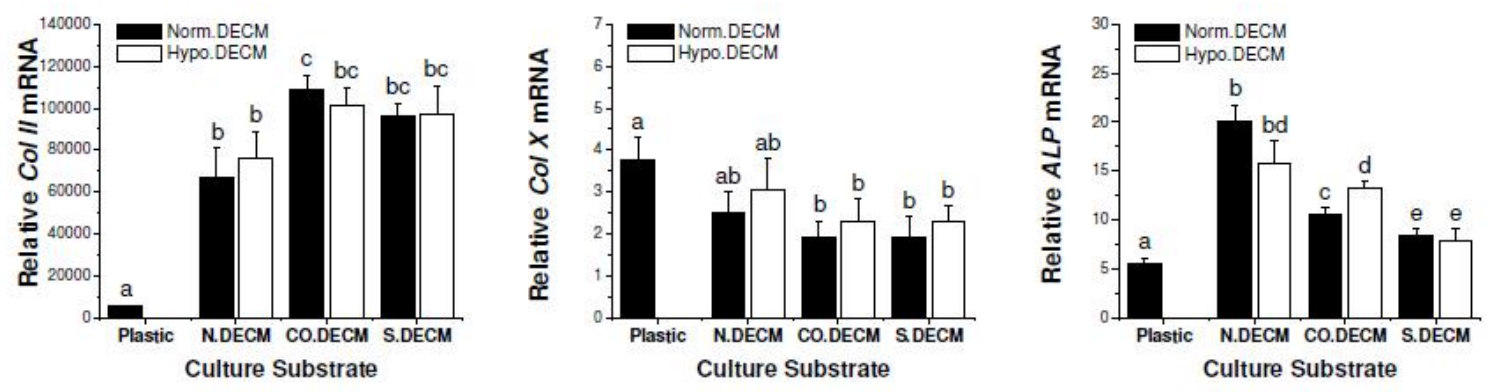

Figure 6. Expansion on DECM improved both SDSC viability and chondrogenic capacity in a pellet culture system. (A) Biochemical analysis for DNA and GAG contents in a pellet. Cell viability is shown with either day 7 or day 14 DNA ratios adjusted by day 0 . Chondrogenic index assessed using the ratio of GAG to DNA. (B) Real-time PCR was used to assess chondrogenic 
differentiation at the mRNA level. Collagen II (Col II) mRNA was a marker for chondrogenic differentiation; collagen $X(\mathrm{Col} X)$ and $A L P$ mRNAs were used as markers for hypertrophy. Lower case letters (i.e., a, b, and c) indicate the results of one-way analysis of variance (ANOVA) at $p<0.05$. Groups with a letter in common are not statistically different from one another. Error bars represent the mean $\pm \mathrm{SD}$ for $\mathrm{n}=4$.

\subsection{Experiment 2: NPC expansion on DECM (Figure 7A)}

In this experiment, NPCs were expanded for 1 passage on SDSC produced DECM. To determine if DECM can be customized during the deposition phase, DECMs were produced in either a hypoxic $\left(5 \% \mathrm{O}_{2}\right)$ or normoxic $\left(21 \% \mathrm{O}_{2}\right)$ culture environment. Finally, pellets were additionally cultured during chondrogenic differentiation in either $21 \%$ or $5 \%$ oxygen to assess the effects on matrix production. Gross observation in Figure 7A shows cell density to be drastically higher in DECM groups and a change in morphology to a smaller, thin shape. Additionally, cells propagated along DECM fibers and in a 3D arrangement while plastic cultured cells only propagated along the 2D substrate and remained widely distributed.

\subsection{Experiment 2: Histology and Immunostaining (Figure 7B)}

Gross pellet characteristics were similar to those observed in the previous experiment, showing much larger pellet sizes in all DECM groups. Surprisingly, collagen II immunostaining showed that plastic treated cells produced pellets with collagen II content comparable to DECM groups. Also, the hypoxic S.DECM differentiated in hypoxia produced the lowest observable

levels of collagen II. Collagen type I immunostaining was similarly low in all groups. Staining for GAGs indicated similar levels among groups. 


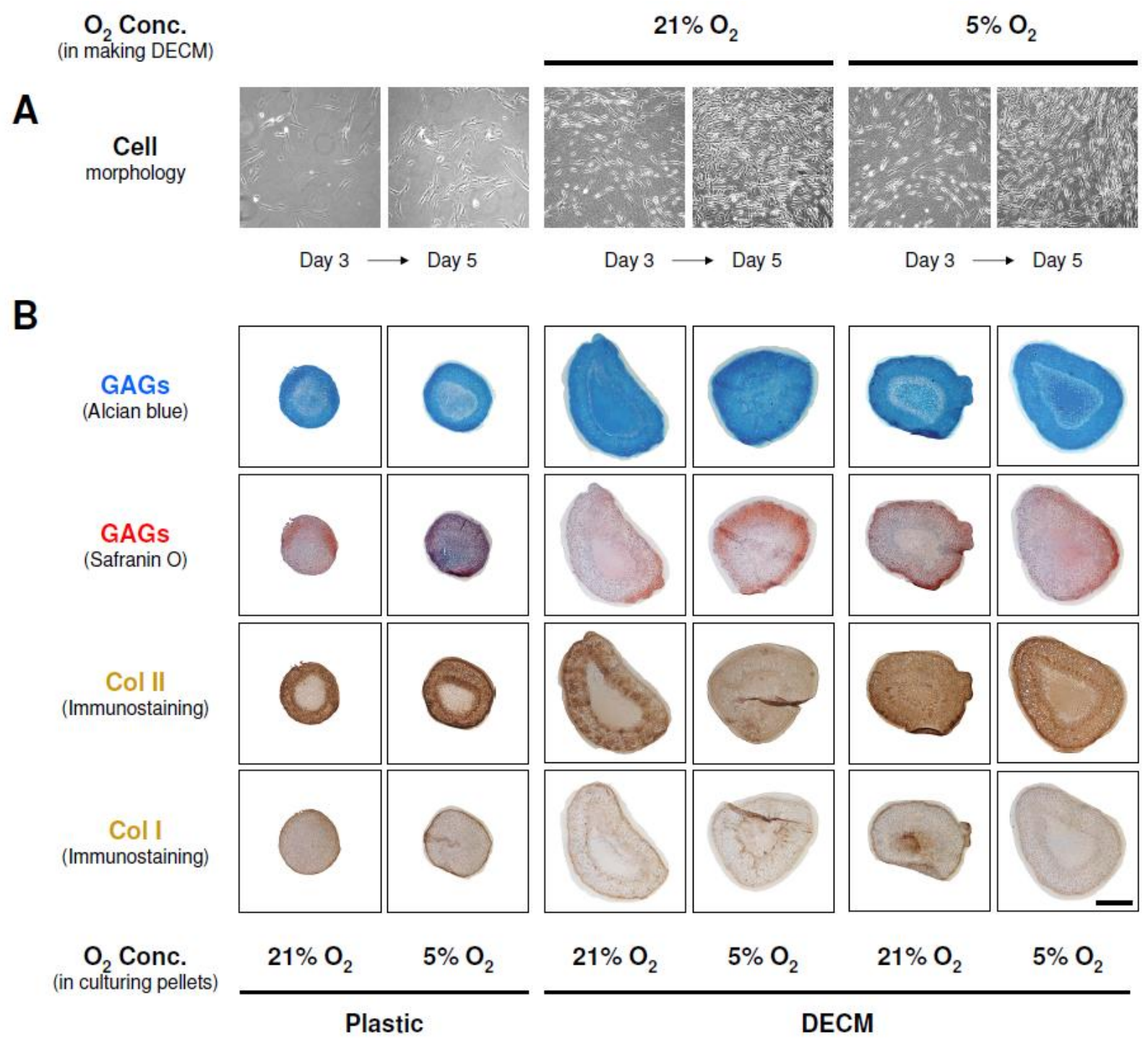

Figure 7. DECM expansion enhanced NPC proliferation and redifferentiation capacity. (A) Passage 2 NPCs were expanded on three substrates for one passage. Cell morphology was photographed at day 3 and day 5 during expansion. (B) Expanded cells were cultured in a serumfree chondrogenic medium in a pellet system for 14 days. Alcian blue and Safranin O staining were used to detect sulfated GAGs. Immunostaining was for collagens I and II. The scale bar is $800 \mu \mathrm{m}$. 


\subsection{Quantitative Biochemical Assessment (Figure 8A)}

At day 7, all DECMs produced higher cell numbers and a significant difference between Hypoxic and Normoxic DECMs was observed. Among groups, 5\% Hypo.DECM produced the highest numbers. By day 14, this difference between the Norm. and Hypo.DECMs became negligent, but cells differentiated in 5\% oxygen maintained the highest numbers assessed by DNA content.

The total GAG content followed a similar trend to that of DNA. Specifically, the $5 \% \mathrm{O}_{2}$ differentiation environment produced the highest GAG content at day 14, but after accounting for DNA content changes, both Norm. and Hypo.DECM produced similar higher levels than other groups. While all DECM groups produced significantly higher levels than plastic, $21 \%$ Norm. and Hypo. DECM groups produced lower levels than 5\% Norm. and Hypo.DECMs.

\subsection{Messenger RNA Analysis (Figure 8B)}

The highest levels of relative collagen II mRNA were found in the 5\% pellets/ Hypo.DECM. While 5\% pellets had similar levels for both Norm.DECM and Hypo.DECM, there was a large significant difference between the two DECMs when pellets were cultured under $21 \% \mathrm{O}_{2}$. The lowest values were found in the $21 \%$ plastic group.

The highest levels of both hypertrophic markers were found in the 5\% S.DECM groups. Both plastic groups produced the lowest relative mRNA levels of Col X mRNA and the 21\% plastic group produced the lowest relative mRNA levels of ALP. Both 5\% DECM groups had the highest collagen X and ALP levels. 

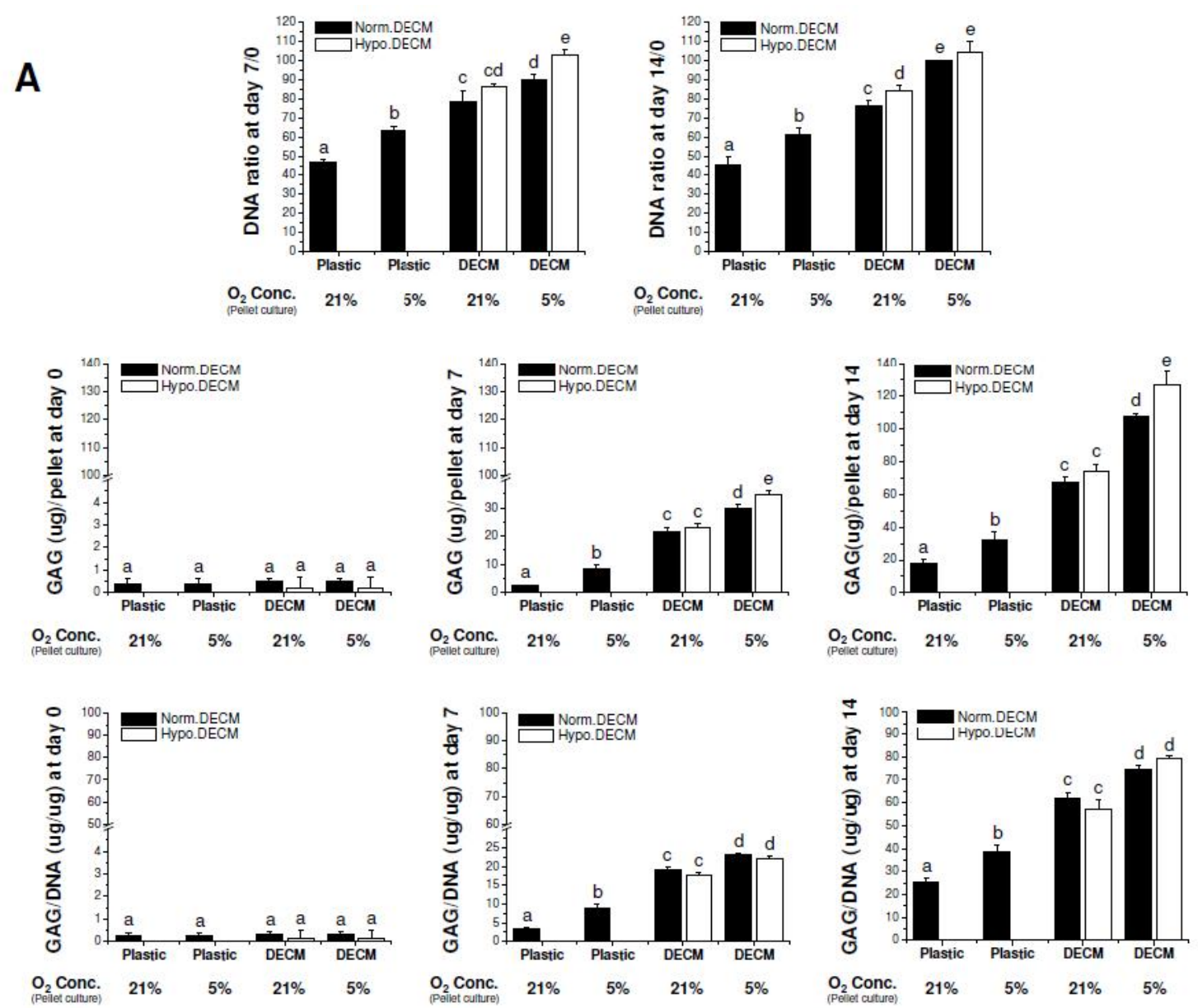

B
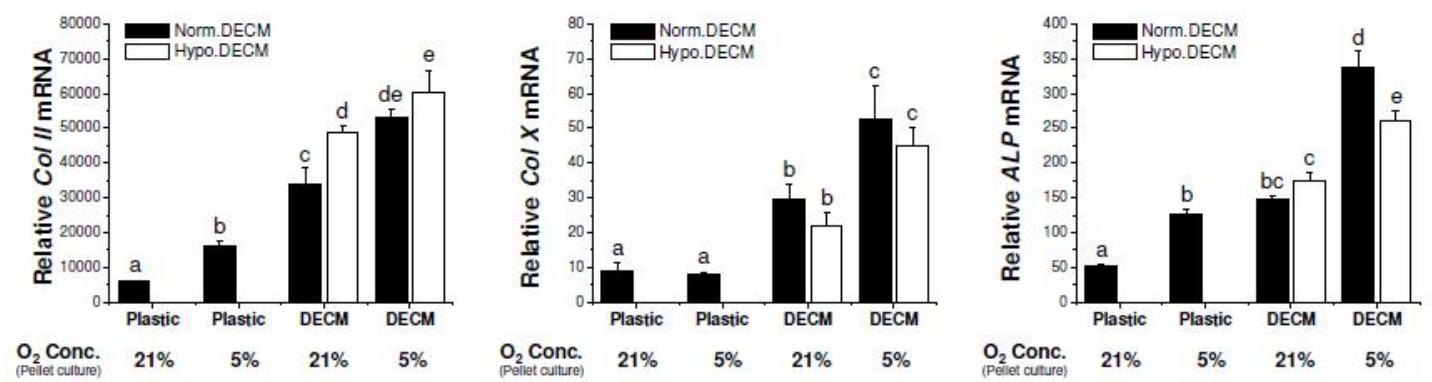

Figure 8 DECM expansion enhanced NPC viability and redifferentiation capacity in a pellet system. (A) Biochemical analysis was used to measure DNA and GAG contents in a pellet. Cell viability was reflected by DNA ratio at day 7 or day 14 adjusted by day 0 . Chondrogenic index was evaluated by ratio of GAG to DNA. (B) Real-time PCR was used to assess NPC redifferentiation at the mRNA level. Collagen II ( $\mathrm{Col}$ II) mRNA was a marker for chondrogenic 
differentiation; collagen $X(\mathrm{Col} X)$ and $A L P$ mRNAs were used as markers for hypertrophy. Lower case letters (i.e., a, b, and c) indicate the results of one-way analysis of variance (ANOVA) at $p<0.05$. Groups with a letter in common are not statistically different from one another. Error bars represent the mean $\pm \mathrm{SD}$ for $\mathrm{n}=4$. 


\section{Chapter 5: Discussion}

(Partially adapted from Pei M, Shoukry M, et al. and Shoukry M, Pei M, et al. [submitted])

\subsection{Overview}

Current autologous nucleus pulposus implantation techniques have failed to achieve success rates and levels necessary for clinical use. These limitations are thought to be the result of the cell population; inadequate monolayer culture environment tends to negatively impact cells with increasing expansion time. There is increasing evidence that suggests pretreatment with the correct conditions during expansion can produce a cell population with greater in vivo success $^{34,58,88}$; this is of particular importance in the IVD due to the hostile microenvironment. When passaged in monolayer on plastic, NPCs are known to proliferate slowly ${ }^{147}$ and undergo increasing dedifferentiation ${ }^{57}$. Cells from the degenerate NP also become increasingly senescent, which makes them minimally responsive to growth factor or cytokine stimulation. They also display a catabolic metabolism characterized by the increased production of matrix degrading enzymes $^{126,69,28}$. Similarly, adult stem cells undergo analogous negative changes with time in two-dimensional (2D) monolayer culture. In this investigation, we explored the use of various DECMs to facilitate both SDSC differentiation and NP redifferentiation toward the NP lineage.

The avascular $\mathrm{NP}^{129}$ relies on diffusion through long distances for nutrient transport; cells must therefore be adapted for a hypoxic and nutrient deprived environment. Blood vessels from the vertebral bodies extend across the superficial regions of endplates ${ }^{55}$. Additionally, small, sparsely distributed vascular beds extend to the dorsal and ventral surfaces of the annulus fibrosus but never penetrate the NP, even after major disc disruption ${ }^{49}, 98$. In agreement, oxygen concentrations are lowest and lactate concentrations highest in the $\mathrm{NP}^{8}$. The lack of vasculature 
produces the accumulation of anerobic metabolism byproducts which produce a low $\mathrm{pH}^{144}$ and high osmolarity ${ }^{71}$. The NP can therefore be concluded to exist in a hypoxic niche where cells express a unique phenotype that differentiates them from those of surrounding tissues ${ }^{118}$. Because the hypoxia is also associated with inhibition of cellular senescence ${ }^{152}$, it is of unique importance for cell based NP regeneration techniques, especially those using stem cells.

Sufficient and high-quality cells, either tissue-specific SDSCs or NPCs, are critical for the success of cell-based NP tissue engineering and regeneration. Our current study demonstrated that DECM deposited by SDSCs, NPCs, or a combination could provide a robust cell expansion system for SDSC proliferation. However, S. DECM provided the highest mitotic effect. Compared to cells expanded on plastic, DECM expanded SDSCs also exhibited a strong chondrogenic differentiation capacity, particularly for S.DECM and CO.DECM. Intriguingly, DECM prepared under normoxia yielded SDSCs with higher cell viability and chondrogenic index but it was not a significant difference compared to hypoxia. DECM deposited by SDSCs was chosen for Experiment 2 due to its robust cell expansion and chondrogenic capacity. We found that DECM prepared under hypoxia favored NPC viability and GAG production as well as collagen II mRNA expression and decreased NPC hypertrophy, as evidenced by lower mRNA levels of collagen $X$ and $A L P$. Moreover, low oxygen in a pellet culture system dramatically enhanced NPC viability and redifferentiation capacity.

\subsection{Experiment 1 Discussion}

In experiment 1, SDSCs were expanded for one passage on S.DECM, N.DECM, or Co.DECM, or plastic; each DECM was produced by cells under either normoxic or hypoxic conditions. After one passage, cell counting demonstrated that the highest SDSC numbers were 
produced by the normoxia and hypoxia produced S.DECMs, with the hypoxia produced S.DECM producing slightly higher numbers. After 14 days of pellet culture under hypoxic conditions in serum free chondrogenic medium, RT-PCR analysis showed the highest total GAG production for normoxic CO. and S.DECMS, but variability was diminished after accounting for DNA content. Because DNA content provides a measure of cell numbers, day 14 results indicate that the higher absolute GAG contents are a result of higher cell numbers. Both N.DECM groups produced the lowest levels of collagen type II and GAG mRNA at day 14, suggesting that N.DECM may not be a good option as part of the in vitro environment for SDSCs. The relative mRNA contents of collagen type $\mathrm{X}$, a marker of undesirable terminal differentiation was at the lowest levels for both CO.DECM and S.DECM groups. Additionally, ALP levels indicative of undesirable mineralization were lowest at the same level for both S.DECM groups. In this experiment, only $5 \%$ oxygen during SDSC differentiation in pellet culture was applied since this reflects the environment in vivo and is in agreement with experiment 2 where NPC redifferentiation occurs best under hypoxic conditions.

Especially for MSCs which may not express traits necessary for survival and proper function in a low oxygen environment, hypoxic preconditioning may provide a good strategy. When treated with hypoxia, MSC viability is increased and rates of apoptosis are decreased postimplantation ${ }^{116}$. One mechanism this occurs is through HIF-1 $\alpha^{22}$ expression which is continually expressed in NP cells and may therefore provide a good method to both enhance post implantation survival and prime cells for differentiation towards an NP like lineage. Because gene expression and metabolic activity of cells cultured in hypoxia is different compared to cells under normal oxygen tension, we hypothesized in this experiment that hypoxic DECM would favor NPC redifferentiation. Our results indicated that the two types of DECM impacted NPCs 
differently with respect to GAG mRNA expression. This suggests that hypoxic DECM varies in either composition or structure.

Another other interesting finding in this experiment was that DECM deposited by a coculture of NPCs and SDSCs produced almost the same results as DECM deposited by SDSCs alone. In contrast, while NPC deposited DECM provided a much improved substrate compared to plastic, it ranked lowest among other DECM groups. A reasonable assumption is that all cells during culture are active producers of DECM. Therefore, a reasonable conclusion is that SDSCs were able to favorably and significantly impact NPC behavior to produce a DECM with almost the same properties as SDSC only produced DECM. These results suggest that NPCs and SDSCs are able to work together well in a culture environment, and more importantly, that SDSCs may play an important role in reprogramming NPCs. These results support analogous findings where transplanted SDSCs suppressed MMP gene activity NP cells ${ }^{92}$ and taken together suggest that SDSCs coculture may be a useful tool in influencing NPC behavior while creating a tissue specific microenvironment. However, further studies are needed to uncover the underlying mechanism for SDSC regulation of NPC behavior.

\subsection{Experiment 2 Discussion}

In experiment 2, NPCs were expanded for one passage on S.DECM produced under either hypoxic or normoxic conditions, then cultured in serum free chondrogenic medium under either hypoxic or normoxic conditions. At day 14, the highest absolute GAG content was observed in the Hypo.DECM and 5\% during pellet culture. After accounting for DNA content, the difference was maintained, though only by a slight margin after accounting for error. This group also displayed the highest levels of relative collagen II mRNA. While the levels of 
collagen type X mRNA at day 14 were similar for both 5\% pellet culture groups, ALP mRNA was lower for ALP mRNA. Importantly, ALP provides a measure of mineralization which is undesirable for the NP. Therefore, for NPCs, hypoxia during SDSC depositition of DECM additionally functions with hypoxia during redifferentiation. This is an important finding because it indicates better overall tissue quality and cell viability under hypoxic conditions, similar to those found in the native NP and may produce higher quality tissue in vivo.

Together, these results have important implications for autologous NP implantation techniques. If NPCs remain as the chosen cell source for autolgous techniques, then it is suggested that the required in vitro expansion should incorporate DECM as a key component of the in vitro expansion microenvironment. In agreement with a recently published concurrent study from our lab, SDSC deposited DECM has a very strong beneficial impact on NPCs. This includes dramatically increased proliferation ability for at least 6 passages in vitro and upregulation of key gene expression including collagen type II, aggrecan, and Sox $9^{56}$. Additionally, this study by $\mathrm{He}$ et al. found an increase in CD90 expression. As a stem cell surface marker positively related to immunosuppressive capacity ${ }^{117}$, higher CD90 expression suggests DECM may also promote the reprogramming of cells with immunosuppressive traits.

In this experiment we additionally demonstrated that the DECM properties may further be attenuated using hypoxia to increase GAG production. Additionally, DECM deposited under hypoxia resulted in lower ALP expression that DECM deposited under normoxia, suggesting an additional impact on undesirable mineral deposition during differentiation. Unfortunately, NPC expansion on NPC deposited DECM could not be evaluated due to study size. However, a similar recent study in chondrocytes comparing chondrocyte deposited DECM with SDSC deposited DECM on chondrocyte expansion and redifferentiation indicated that SDSCs can 
produce the best substrate ${ }^{111}$. Similarities between chondrocytes and NPCs might suggest that the results would be similar in NPCs, but this has yet to be investigated. Additionally, DECM in this study was deposited under normoxia, so the beneficial effects of hypoxia during DECM deposition have yet to be verified. Additionally, while speculation can be made regarding the mechanisms underlying hypoxia induced DECM differences; further study is needed to reveal them.

\subsection{Mechanisms Underlying Hypoxia}

The effects of hypoxia are regulated by the hypoxia inducible factor (HIF) group of transcription factors, whose family of HIF target genes regulates key cellular functions, including energy metabolism, angiogenesis, cell survival, apoptosis, matrix synthesis, proliferation, selfrenewal, and differentiation ${ }^{123}$. Serving as the key regulator of energy metabolism and survival, HIF-1 is a heterodimer consisting of an $\alpha$ and a $\beta$ subunit, with the former degrading quickly under normoxic conditions ${ }^{134,}{ }^{148}$. Another key isoform, HIF-2 $\alpha$, has some common action with HIF-1 but also serves as a regulator for genes unresponsive to HIF- $1^{79}$. The response to HIF-1 and HIF-2 are cell specific. For example, only HIF-2 was found to be a regulator of Sox9 in chondrocytes $^{76}$, but the hypoxic response of BMSCs includes HIF-1 $\alpha$ regulation of the same gene ${ }^{67,28}$. Therefore, the combined action of HIF-1 and HIF-2 is considered to be dependant on cell type ${ }^{138}$.

A central function of HIF-1 $\alpha$ is in promoting transcription of glycolytic enzymes essential for cells to switch from aerobic to anerobic metabolism ${ }^{134,135}$ in part by inhibiting ATP production through oxidative phosphorylation ${ }^{107}$. One unique trait of NPCs is the continued expression of HIF-1 $\alpha$ under normoxic conditions, whereas in other cell types this isoform is 
quickly degraded ${ }^{125}$. Known to be involved controlling mineralization in various tissues including bone, the calcified zone of the growth plate, and the degenerate NP, ANK expression is negatively regulated by both HIF-1 and HIF-2 in the NP and is thought to prevent mineralization under physiological conditions ${ }^{137}$. A decrease in aggrecan expression is also observed upon HIF1 inhibition, suggesting the unique oxygen-independent stabilization of HIF-1 $\alpha$ is an important metabolic adaptation for both glycolysis and aggrecan expression ${ }^{3}$. This finding further supports the recent report that NPC metabolism is not reduced at $\mathrm{O}_{2}$ concentrations as low as $1 \%$ and that the hypoxic environment positively impacts aggrecan production while promoting a healthy gelatinous as opposed to fibrous matrix ${ }^{94}$.

Additionally, HIF-2 also was found to regulate the p300 binding protein cited 2 which regulates both HIF-1 and HIF-2 dependent vascular endothelial growth factor (VEGF) expression in $\mathrm{NPCs}^{2}$. Another key consequence of the low oxygen environment in NP cells is promoting the expression of proteins responsible for Notch signaling, an important regulator of proliferation $^{59}$. Hypoxic activation of the PI3K/Akt and MAPK pathways is thought to underly the downregulation of apoptosis in healthy NP cells in a hypoxic, serum deprived environment ${ }^{122}$. Hypoxia also induces expression of the Notch gene related to maintaining an undifferentiated state and cell fate determination ${ }^{73,48}$. These mechanisms may have played a role in producing the variation in DECM properties observed in this study, but further studies are needed to determine the specific response. The significant positive results suggest that SDSC DECM may have important utility as a biomaterial for NP tissue engineering. It is suggested that the first step in developing this technology for future use is characterizing the composition and stiffness of this substrate, since this would yield important clues for understanding the cellular response. 


\subsection{Conclusion}

As a substrate for in vitro expansion, DECM provides a highly superior surface that drastically increases proliferation and strengthens both stem cell differentiation towards the NP lineage and NP redifferentiation. Additionally, these beneficial effects can be mediated by hypoxia. This suggests that in the future, growth factors might be used in an analogous fashion to further customize DECMs. The requirement for high numbers of metabolically active cells for autologous techniques can be met by the inclusion of DECM as part of the in vitro microenvironment. 


\section{References}

1. Adams MA, Roughley PJ. What is intervertebral disc degeneration and what causes it? Spine (Phila Pa 1976) 2006;31:2151-2161

2. Agrawal A, Gajghate S, Smith H, et al. Cited2 Modulates Hypoxia-Inducible FactorDependent Expression of Vascular Endothelial Growth Factor in Nucleus Pulposus Cells of the Rat Intervertebral Disk. Arthritis \& Rheumatism 2008;58(12):3798-3808.

3. Agrawal A, Guttapalli A, Narayan S, et al. Normoxic stabilization of HIF-1 $\alpha$ drives glycolytic metabolism and regulates aggrecan gene expression in nucleus pulposus cells of the rat intervertebral disk. Am J Physiol Cell Physiol 2007;293:C621-31

4. Allon AA, Aurouer N, Yoo BB, et al. Structured Bilaminar Co-Culture Outperforms Stem Cells and Disc Cells in a Simulated Degenerate Disc Environment. Spine (Phila Pa 1976) 2011; doi:10.1097/BRS.0b013e31823b055f

5. Allon AA, Aurouer N, Yoo BB, et al. Structured Co-culture of Stem Cells and Disc Cells Prevent Degeneration in a Rat Model. Spine J 2010;10(12):1089-1097

6. Antoniou J, Goudsouzian NM, Heathfield TF, et al. The human lumbar endplate. Evidence of changes in biosynthesis and denaturation of the extracellular matrix with growth, maturation, aging, and degeneration. Spine 1996;21:1153-1161

7. Antoniou J, Steffen T, Nelson F, et al. The human lumbar intervertebral disc: evidence for changes in the biosynthesis and denaturation of the extracellular matrix with growth, maturation, ageing, and degeneration. J Clin Invest 1996;98:996-1003

8. Bartels EM, Fairbanks JC, Winlove CP, Urban JP. Oxygen and lactate concentrations measured in vivo in the intervertebral discs of patients with scoliosis and back pain. Spine (Phila Pa 1976) 1998;23(1):1-7

9. Benneker LM, Heini PF, Alini M, et al. 2004 Young investigator award winner: vertebral endplate marrow contact channel occlusions and intervertebral disc degeneration. Spine (Phila $\mathrm{Pa}$ 1976) 2005;30(2):167-173

10. Blanco JF, Graciani IF, Sanchez-Guijo FM, et al. Isolation and characterization of mesenchymal stromal cells from human degenerated nucleus pulposus: comparison with bone marrow mesenchymal stromal cells from the same subjects. Spine (Phila PA 1976) 2010;35(26):2259-65

11. Boden SD, Davis DO, Dina TS, et al. Abnormal magnetic-resonance scans of the lumbar spine in asymptomatic subjects. A prospective investigation. J Bone Joint Surg Am. 1990;72:4030408

12. Bogduk, N. The lumbar disc and low back pain. Neurosurg. Clin. N. Am. 1991;2(4):791-806 
13. Boos N, Weissbach S, Rohrbach H, et al. Classification of age-related changes in lumbar intervertebral discs: 2002 Volvo Award in basic science. Spine (Phila Pa 1976) 2002;27(23):2631-44

14. Brittberg M, Lindahl A, Nilsson A, et al. Treatment of deep cartilage defects in the knee with autologous chondrocyte transplantation. N Engl J Med 1994;331:889-859

15. Bruehlmann SB, Rattner JB, Matyas JR, et al. Regional variations in the cellular matrix of the annulus fibrosus of the intervertebral disc. J Anat 2002;201:159-171

16. Buckwalter JA. Aging and degeneration of the human intervertebral disc. Spine (Phila Pa 1976) $1995 ; 20(11): 1307-14$

17. Campioni D, Rizzo R, Stignani M et al. A decreased positivity for CD90 on human mesenchymal stromal cells (MSCs) is associated with a loss of immunosuppressive activity by MSCs. Cytometry B Clin Cytom 2009;76:225-30

18. Campisi J. The biology of replicative senescence. Eur J Cancer 1997;33:703-709

19. Caplan AI. Adult Mesenchymal Stem Cells for Tissue Engineering Versus Regenerative Medicine. J Cell Physiol 2007;213(2):341-347

20. Cappello R, Bird JLE, Pfeiffer D, et al. Notochordal cell produce and assemble extracellular matrix in a distinct manner, which may be responsible for the maintenance of healthy nucleus pulposus. Spine (Phila Pa 1976) 2006;31(8):873-882

21. Cassidy JJ, Hiltner A, Baer E. Hierarchial structure of the intervertebral disc. Connect Tissue Res 1989;23:75-88

22. Chacko SM, Ahmed S, Selvendiran K, et al. Hypoxic preconditioning induces the expression of prosurvival and proangionic markers in mesenchymal stem cells. Am J Physiol Cell Physiol 2010;299(6):C1562-70

23. Chen J, Jing L, Glichrist CL, et al. Expression of Laminin Isoforms, Receptors and Binding Proteins Unique to Nucleus Pulposus Cells of Immature Intervertebral Disc. Connect Tissue Res 2009; 50(5):294-306

24. Chen S, Emery SE, Pei M. Coculture of synovium-derived stem cells and nucleus pulposus cells in serum-free defined medium with supplementation of transforming growth factor-beta1: a potential application of tissue-specific stem cells in disc regeneration. Spine (Phila Pa 1976) 2009; 34(12):1272-80

25. Chesterman PJ, Smith AU. Homotransplantation of articular cartilage and isolated chondrocytes: an experimental study in rabbits. J Bone Joint Surg Br 1968;50:184-197 
26. Cheung KM, Karppinen J, Chad D, et al. Prevalence and pattern of lumbar magnetic resonance imaging changes in a population study of one thousand forty-three individuals. Spine (Phila Pa 1976) 2009;34:934-40

27. Colognato H, Yurchenco PD. Form and function: the laminin family of heterotrimers. Dev Dyn 2000;218:213-34

28. Cristofalo VJ, Lorenzini A, Allen RG, et al. Replicative senescence: a critical review. Mech Ageing Dev 2004;125:827-848

29. Das DB, Welling A, Urban JP, et al. Solute transport in intervertebral disc: experiments and finite element modeling. Ann N Y Acad Sci 2009;1161:44-61

30. Di Martino A, Vaccaro AR, Lee JY, et al. Nucleus pulposus replacement: basic science and indications for clinical uses. Spine (Phila Pa 1976) 2005; 30:S16-22

31. Erwin WM, Ashman K, O'Donnel P, et al. Nucleus pulposus notochord cells secrete connective tissue growth factor and up-regulate proteoglycan expression by intervertebral disc chondrocytes. Arthritis Rheum 2006;54(12):3859-3867

32. Eyre DR, Muir H. Types I and II collagens in human intervertebral discs. Interchanging radial distributions in the annulus fibrosus. Biochem J 1976;157:267-270

33. Eyre DR, Muir H. Quantitative analysis of types I and II collagens in human intervertebral disc at various ages. Biochim Biophys. Acta 1977;492:29-42

34. Feng $\mathrm{G}$, Jin $\mathrm{X}, \mathrm{Hu} \mathrm{J}$, et al. Effects of hypoxias and scaffold architecture on rabbit mesenchymal stem cell differentiation towards a nucleus pulposus-like phenotype. Biomaterials. 2011;32(32):8182-9

35. Fife RS, Caterson B, Myers SL. Identification of link proteins in canine synovial cell cultures and canine articular cartilage. J Cell Biol 1985;100:1050-5

36. Freeman BJ, Davenport J. Total disc replacement in the lumbar spine: a systematic review of the literature. Eur Spine J 2006; Suppl 3: S439-447

37. Freemont AJ. The cellular pathobiology of the degenerate intervertebral disc and discongenic back pain. Rheumatology 2009;48:5-10

38. Fritzell P, Hagg O, Wessberg P, et al. 2001 Volvo Award Winner in Clinical Studies: Lumbar Fusion Versus Nonsurgical Treatment for Chronic Low Back Pain: A Multicenter Randomized Controlled Trial From the Swedish Lumbar Spine Study Group. Spine (Phila Pa 1976) 2001;26(23):2521-2532 
39. Ganey T, Libera J, Moos V, et al. Disc chondrocyte transplantation in a canine model: a treatment for degenerated or damaged intervertebral disc. Spine (Phila PA 1976) 2003;28(23):2609-20

40. Geiger B, Bershadsky A, Pankov R, et al. Transmembrane crosstalk between the extracellular matrix and the cytoskeleton. Nat Rev Mol Cell Biol 2001;2:793-8056

41. Gibson JN, Grant IC, Waddell G. The Cochrane review of surgery for lumbar disc prolapse and degenerative lumbar spondylosis. Spine (Phila Pa 1976) 1999;24:1820-1832

42. Gilchrist CL, Chen J, Richardson WJ, et al. Functional Integrin Subunits Regulating CellMatrix Interactions in the Intervertebral Disc. Journal of Orthopaedic Research 2007;25:829-840

43. Gilchrist CL, Darling EM, Chen J, et al. Extracellular Matrix Ligand and Stiffness Modulate Immature Nucleus Pulposus Cell-Cell Interactions. PLos One 2011;6(11):e27170

44. Glichrist CL, Francisco AT, Plopper GE, et al. Nucleus Pulposus Cell-Matrix Interactions with Laminins. European Cells and Materials 2011;21:523-532

45. Golub EE, Boesze-Battaglia K. The role of alkaline phosphatase in mineralization. Current Opinion in Orthopedics 2007;18(5):444-448

46. Gorensek M, Jaksimovic C, Kregar-Velikonja N, et al. Nucleus pulposus repair with cultured autologous elastic cartilage derived chondrocytes. Cell Mol Biol Lett 2004;9(2):363-73

47. Gregory CA, Ylostalo J, Prockop DJ. Adult bone marrow stem/progenitor cells (MSCs) are preconditioned by microenvironmental "niches" in culture: a two-stage hypothesis for regulation of MSC fate. Sci STKE 2005;2005(94):pe37

48. Grogan SP, Olee T, Hiraoka K, et al. Repression of chondrogenesis through binding of Notch signaling proteins HES-1 and HEY-1 to N-box domains in the COL2A1 enhancer site. Arthritis Rheum 2008;58:2754-2763

49. Gruber HE, Ashraf N, Kilburn J, et al. Vertebral endplate architecture and vascularization: application of micro-computerized tomography, a vascular tracer, and immunocytochemistry in analyses of disc degeneration in the aging sand rat. Spine (Phila Pa 1976) 2005, 30:2593-2600

50. Gruber HE, Hanley EN Jr. Analysis of aging and degeneration of the human intervertebral disc. Comparison of surgical speciments with normal controls. Spine (Phila Pa 1976) 1998;23(7):751-757

51. Gruber HE, Ingram JA, Norton HJ, et al. Senescence in cells of the aging and degenerating intervertebral disc: immunolocalization of senescence-associated $\beta$-galactosidase in human and sand rat discs. Spine (Phila Pa 1976) 2007;32:321-327 
52. Gruber HE, Norton HJ, Leslie K, et al. Clinical and demographic prognostic indicators for human disc cell proliferation in vitro: pilot study. Spine (Phila PA 1976) 2001;26(21):2323-7

53. Grunhagen T, Wilde G, Soukane DM, et al. Nutrient supply and intervertebral disc metabolism. J Bone Joint Surg Am 2006;Suppl2:30-35

54. Hamerman D, Smith C, Keiser HD, et al. Glycosaminoglycans produced by human synovial cell cultures. Coll Relat Res 1982;2:313-29

55. Hassler O: The human intervertebral disc: A micro-angiographical study on its vascular supply at various ages. Acta Orthop Scand 1969;40:765-772

56. He F, Pei M. Rejuvenation of Nucleus Pulposus Cells Using Extracellular Matrix Deposited by Synovium-Derived Stem Cells. Spine (Phila Pa 1976); 2011 (In press)

57. Hegewald AA, Endres M, Abbushi A, et al. Adequacy of herniated disc tissue as a cell source for nucleus pulposus regeneration. J Neurosurg Apine 2011;14:273-280

58. Herrmann JL, Abarbanell AM, Weil BR, et al. Optimizing stem cell function for the treatment of ischemic heart disease. J Surg Res. 2011;166(1):138-45

59. Hiyama A, Skubutyte R, Markova D, et al. Hypoxia Activates the Notch Signaling Pathway in Cells of the Intervertebral Disc. Arthritis \& Rheumatism 2011;65(6):1355-1364

60. Hoemann CD, El-Gabalawy H, McKee MD. In vitro osteogenesis assays: influence of the primary cell source on alkaline phosphatase activity and mineralization. Pathol Biol (Paris) 2009;57(4):318-23

61. Holm S, Maroudas A, Urban JP et al. Nutrition of the intervertebral disc: solute transport and metabolism. Connect Tissue Res 1981;8:101-119

62. Humzah MD, Somates RW. Human intervertebral disc: structure and function. Anat. Rec 1988;220:337-356

63. Iatridis JC. Tissue engineering: Function follows form. Nature Materials 2009;8:923-924

64. Iatridis JC, Maclean JJ, O'Brien M, Stokes AF. Measurements of Proteoglycan and Water Content Distribution in Human Lumbar Intervertebral Discs. Spine 2007;32:1493-1397

65. Ishii T, Tsuji H, Sano A, Katoh Y, et al. Histochemical and ultrastructural observations on brown degeneration of human intervertebral disc. J Orthop Res 1991;9:78-90

66. Kandel RA, Hamilton D, Seguin C, et al. An in vitro tissue model to study the effect of age on nucleus pulposus cells. Eur Spine J 2007;16(12):2166-73 
67. Kanichai M, Ferguson D, Prendergast PJ, et al. Hypoxia promotes chondrogenesis in rat mesenchymal stem cells: a role for AKT and hypoxia-inducible factor (HIF)-1alpha. J Cell Physiol 2008;216:708-715

68. Katz JN. Lumbar Disc Disorders and Low-Back Pain: Socioeconomic Factors and Consequences. Journal of Bone and Joint Surgery 2006;88-A:21-24

69. Kim KW, Chung HN, Ha KY, et al. Senescence mechanisms of nucleus pulposus chondrocytes in human intervertebral discs. The Spine Journal 2009;9:658-666

70. Kim KW, Kim YS, Ha KY, et al. An autocrine or paracrine Fas-mediated counterattack: a potential mechanism for the apoptosis of notochordal cells in intact rat nucleus pulposus. Spine (Phila Pa 1976) 2005;30:1247-1251.

71. Kitagawa R, Bakkenist CJ, McKinnon PJ, et al. Phosphorylation of SMC1 is a critical downstream event in the ATM-NBS1-BRCA1 pathway. Genes Dev 2004;18:1423-1438

72. Klara PM, Ray CD. Artificial nucleus replacement: clinical experience. Spine (Phila Pa 1976) 2002;27(12):1374-7

73. Kobayashi T, Mizuno H, Imayoshi I, et al. Hypoxia-mediated activation of D114-NotchHey2 signaling in endothelial progenitor cells and adoption of arterial cell fate. Exp Cell Res 2007;313:1-9

74. Kowalski RJ, Ferrara LA, Benzel EC. Biomechanics of the spine. Neurosurg Q 2005;15(1):42-59

75. Kruegel J, Miosge N. Basement membrane components are key players in specialized extracellular matrices. Cell Mol Life Sci 2010;67:2878-2895

76. Lafont JE, Talma S, Murphy CL. Hypoxia-inducible factor 2alpha is essential for hypoxic induction of human articular chondrocyte phenotype. Arthritis Rheum 2007;56:3297-3306

77. Le Maitre CL, Freemont AJ. Hoyland JA. Accelerated cellular senescence in degenerate intervertebral discs: a possible role in the pathogenesis of intervertebral disc degeneration. Arthritis Res. 2007;9:R45

78. Le Maitre CL, Freemont AJ, Hoyland JA. Human disc degeneration is associated with increased MMP 7 expression. Biotech HIstochem 2006;81(4-6):125-131

79. Loboda A, Jozkowicz A, Dulak J. HIF-1 and HIF-2 Transcription Factors - Similar but Not Identical. Mol Cells 2010;29:435-442

80. Lotz JC, Hadi T, Bratton C, et al. Anulus fibrosus tension inhibits degenerative structural changes in lamellar collagen. Eur Spine J 2008;17:1149-1159 
81. Luoma K, Riihimaki H, Luukkonen $\mathrm{R}$ et al. Low back pain in relation to lumbar disc degeneration. Spine 2000;25:4870492

82. Magnier C, Boiron O, Wendling-Mansuy S, et al. Nutrient distribution and metabolism in the intervertebral disc in the unloaded state: a parametric study. J Biomech 2009;42(2):100-108

83. Marchand F, Ahmed AF. Investigation of the laminate structure of lumbar disc annulus fibrosus. Spine (Phila Pa 1976) 1990;15:402-410

84. Maroudas A, Stockwell RA, Nachemson A et al. Factors involved in nutrition of the human lumbar intervertebral disc: Cellularity and diffusion of glucose in vitro. J Anat 1975;120:113-130

85. Martin MD. Boxell CM, Malone DG. Pathophysiology of lumbar disc degeneration: a review of the literature. Neurosurg Focus 2002;13(2):E1

86. McCann MR, Bacher CA, Sequin CA. Exploiting notochord cells for stem cell-based regeneration of the intervertebral disc. J Cell Commun Signal 2011;5(1):39-43

87. Melrose J, Ghosh P, Taylor TK. A comparative analysis of the differential spatial and temporal distribution of the large (aggrecan, versican) and small (decorin, biglycan, fibromodulin) proteoglycans of the intervertebral disc. J Anat 2001;30:893-899

88. Mias C, Trouche E, Sequelas MH, et al. Ex vivo pretreatment with melatonin improves survival, proangiogenic/mitogenic activity, and efficiency of mesenchymal stem cells injected into ischemic kidney. Stem cells 2008;26(7):1749-57

89. Miller J, Schmatz C, Schultz A: Lumbar disc degeneration: Coorelation with Age, Sex, and Spine Level in 600 Autopsy Specimens. Spine 1988, 13:173-178.

90. Miner JH, Yurchenco PD. Laminin functions in tissue morphogenesis. Annu Rev Cell Dev Biol 2004;20:255-284

91. Miraz SK, Deyo RA. Systematic review of randomized trials comparing lumbar fusion surgery to nonoperative care for treatment of chronic back pain. Spine (Phila Pa 1976) 2007;32:816-23.

92. Miyamoto $\mathrm{T}$, Muneta $\mathrm{T}$, Tabuchi $\mathrm{T}$, et al. Intradiscal transplantation of synovial mesenchymal stem cells prevents intervertebral disc degeneration through suppression of matrix metalloproteinase-related genes in nucleus pulposus cells in rabbits. Arthritis Res Ther 2010;12(6):R206

93. Moseley JB, Anderson AF, Browne JE, et al. Long-term durability of autologous chondrocyte implantation: a multicenter, observational study in US patients. Am J Sports Med 2010;38(2):238-46 
94. Mwale F, Ciobanu I, Giannitsios D, et al. Effect of Oxygen Levels on Proteoglycan Synthesis by Intervertebral Disc Cells. Spine (Phila Pa 1976) 2011a;36(2):E131-E138

95. Mwale F, Rampersad S, Richard H. The constitutive expression of type $x$ collagen in mesenchymal stem cells from osteoarthritis patients is reproduced in a rabbit model of osteoarthritis. J Tissue Eng 2011;2011:58754

96. Mwale F, Roughley P, Antoniou J. Distinction between the Extracellular Matrix of the Nucleus Pulposus and Hyaline Cartilage: A Requisite for Tissue Engineering of the Intervertebral Disc. Eur Cell Mater 2004;8:58-63

97. Neame PJ, Kay CJ, McQuillan DJ, et al. Independent modulation of collagen fibrillogenesis by decorin and lumican. Cell Mol Life Sci 2000;57(5):859-63

98. Nerlich AG, Schaaf R, Walchli B, Boos N. Temporo-spatial distribution of blood vesssels in human lumbar intervertebral discs. Eur Spine J 2007;16(4):547-555

99. Nettles DL, Richardson WJ, Setton LA. Integrin expression in cells of the intervertebral disc. J Anat 2004;204:515-520

100. Nimura A, Muneta $\mathrm{T}$, Koga $\mathrm{H}$, et al. Increased proliferation of human synovial mesenchymal stem cells with autologous human serum: comparisons with bone marrow mesenchymal stem cells and with fetal bovine serum. Arthritis Rheum 2008;58:501-510

101. Nishimura K, Mochida J. Percutaneous reinsertion of the nucleus pulposus. An experimental study. Spine 1998;23:1531-1538

102. Niu CC, Yuan LJ, Lin SS, et al. Mesenchymal stem cell and nucleus pulposus cell coculture modulates cell profiles. Clin Orthop Relat Res 2009;467(12):3263-72

103. O'Connell GD, Vresilovic EJ, Elliott DM. Human intervertebral disc internal strain in compression: The effect of disc region, loading position, and degeneration. J Orthop Res 2011;29(4):547-555

104. Oegema TR. Biochemistry of the intervertebral disc. Clin Sports Med 1993;12:419-439

105. Ogata K, Whiteside LA. 1980 Volvo award winner in basic science. Nutritional pathways of the intervertebral disc. An experimental study using hydrogen washout technique. Spine 1981;6:211-6

106. Pacifici M, Koyama E, Iwamoto M, et al. Development of articular cartilage: what do we know about it and how may it occur? Connect Tissue Res 2000;41:175-84.

107. Papandreou I, Cairns RA, Fontana L, et al. HIF-1 mediates adaptation to hypoxia by actively downregulating mitochondrial oxygen consumption. Cell Metab 2006;3:187-97 
108. Pazzaglai UE, Salisbury JR, Byers PD. Development and involution of the notochord in the human spine. J R Soc Med 1989;82:413-415

109. Pei M, He F, Kish V, et al. Engineering of functional cartilage tissue using synoviumderived stem cells. Clin Orthop Relat Res 2008;466:1880-1889

110. Pei M, He F, Vunjak-Novakovic. Synovium-derived stem cell-based chondrogenesis. Differentiation 2008;76(10):1044-56

111. Pei M, He F, Wei L. Three-dimensional cell expansion substrate for cartilage tissue engineering and regeneration: A comparison in decellularized matrix deposited by synoviumderived stem cells and chondrocytes. J Tissue Sci Eng 2011a;2(2):703-12

112. Pei M, Li J, Shoukry M, Zhang Y. A review of decellularized stem cell matrix: a novel cell expansion system for cartilage tissue engineering. Eur Cell Mater 2011b;22:333-43

113. Pei M, Luo JM, Chen Q. Enhancing and maintaining chondrogenesis of synovial fibroblasts by cartilage extracellular matrix protein mantrilins. Osteoarth Cartilage 2008;16(9):1110-7

114. Pei M, Shoukry M, Li J et al. Modulation of In Vitro Microenvironment Facilitates Synovium-Derived Stem Cell-Based Nucleus Pulposus Tissue Regeneration. Spine (Phila Pa 1976) 2012;37(18):1-10

115. Perie DS, Maclean JJ, Owen JP, et al. Correlating material properties with tissue composition in enzymatically digested bovine annulus fibrosus and nucleus pulposus tissue. Ann Biomed Eng 2006;34:769-77

116. Peterson KM, Aly A, LOerman A, et al. Improved survival of mesenchymal stromal cell after hypoxia preconditioning: role of oxidative stress. Life Sci 2011;88(1-2):65-73

117. Purmessur D, Schrek RM, Abbott RD, et al. Notochordal conditioned media from tissues increases proteoglycan accumulation and promotes a healthy nucleus pulposus phenotype in human mesenchymal stem cells. Arthritis Res Ther 2011;13(3):R81

118. Rajpurohit R, Risbud MV, Ducheyne P, et al. Phenotypic characteristics of the nucleus pulposus: expression of hypoxia inducing factor-1, glucose transporter-1 and MMP-2. Cell Tissue Res 2002;308(3):401-7

119. Rampersand S, Ruiz JC, Petit A, et al. Stem cells, nitrogen-rich plasma-polymerized culture surfaces, and type X collagen suppression. Tissue Eng Part A 2011;17(19-20):2551-60

120. Rastogi A, Thakore P, Leung A, et al. Environmental Regulation of Notochordal Gene Expression in Nucleus Pulposus Cells. J Cellular Physiology 2009;220:698-705 
121. Richardson SM, Hoyland JA, Mobasheri R, et al. Mesenchymal Stem Cells in Regenerative Medicine: Opportunities and Challenges for Articular Cartilage and Intervertebral Disc Tissue Engineering. Journal of Cellular Physiology 2010;222:23-32

122. Risbud MV, Fertala J, Vresilovic EJ, et al. Nucleus pulposus cells upregulate PI3k/Akt and MEK/ERK signaling pathways under hypoxic conditions and resist apoptosis induced by serum withdrawl. Spine (Phila Pa 1976) 2005;30(8):882-9

123. Risbud MV, Guttapalli A, Stokes DG, et al. Nucleus Pulposus Cells Express HIF-1 $\alpha$ Under Normoxic Culture Conditions: A Metabolic Adaptation to the Intervertebral Disc Environment. J Cell Biochem 2006;98:152-9

124. Risbud MV, Guttapalli A, Tsai TT, et al. Evidence for skeletal progenitor cells in the degenerate human intervertebral disc. Spine 2007;32:2537-44.

125. Risbud MV, Schipani E, Shapiro IM. Hypoxic Regulation of Nucleus Pulposus Cell Survival: from niche to notch. The American Journal of Pathology 2010;176(4):1577-83

126. Roberts S, Evans EH, Kletsas D, et al. Senescence in human intervertebral discs. Eur Spine J 2006;15(Suppl 3):S312-S316

127. Roberts S, Menage J, Duance V, et al. 1991 Volvo award in basic sciences: Collagen types around the cells of the intervertebral disc and cartilage end plate: An immunolocalization study. Spine (Phila Pa 1976) 1991;16:1030-1038

128. Robins JC, Akeno N, Mukherjee A, et al. Hypoxia induces chondrocyte-specific gene expression in mesenchymal cells in association with transcriptional activation of Sox9. Bone 2005;37(3):313-22

129. Rudert M, Tillmann B: Lymph and blood supply of the human intervertebral disc: cadaver study of correlations to discitis. Acta Orthop Scand 1993;64:37-40

130. Sakaguchi Y, Sekiya I, Yagishita K, et al. Comparison of human stem cells derived from various mesenchymal tissues: superiority of synovium as a cell source. Arthritis Rheum 2005;52:2521-9

131. Schizas C, Kulik G, Kosmopoulos V. Disc Degeneration: Current Surgical Options. European Cells and Materials 2010;20:306-315.

132. Segat D, Riccardo C, Di Marco E, et al. Integrins alpha 6a beta 1 and alpha $6 \mathrm{~b}$ beta 1 promote different stages of chondrogenic cell differentiation. J Biol Chem 2002;277:3161231622

133. Selard E, Shirazi-Adl A, Urban JP. Finite element study of nutrient diffusion in the human intervertebral disc. Spine (Phila Pa 1976) 2003;28(17):1945-53 
134. Semenza GL, Roth PH, Fang HM, et al. Transcriptional regulation of genes encoding glycolytic enzymes by hypoxia-inducible factor 1. J Biol Chem 1994;269:23757-23763

135. Semenza GL. Signal transduction to hypoxia-inducible factor 1. Biochemical Pharmacology 2002;64(5-6):993-998

136. Shirasawa S, Sekiya I, Sakaguchi Y, et al. In vitro chondrogenesis of human synoviumderived mesenchymal stem cells: optimal condition and comparison with bone marrow-derived cells. J Cell Biochem 2006;97:84-97

137. Skubutyte R, Markova D, Freeman TA, et al. Hypoxia-Inducible Factor Regulation of ANK Expression in Nucleus Pulposus Cells. Arthritis\& Rheum 2010;62(9):2707-15.

138. Sowter HM, Raval RR, Moore JW, et al. Predominant role of hypoxia-inducible transcription factor (Hif)-1 alpha versus Hif-2 alpha in regulation of the transcriptional response to hypoxia. Cancer Res 2003;63:6130-6134

139. Stevens RL, Ewins RJ, Revell PA, et al. Proteoglycans of the Intervertebral disc. Biochem J 1979;179:561-572

140. Strassburg S, Richardson SM, Freemont AJ, et al. Co-culture indiuces mesenchymal stem cell differentiation and modulation of the degenerate human nucleus pulposus cell phenotype. Regen Med. 2010;5(5):701-11

141. Sztrolovics R, Alini M, Roughley PJ, et al. Aggrecan degradation in human intervertebral discs and articular cartilage. Biochem J 1997;326:235-241

142. Trout JJ, Buckwalter JA, Moore KC, et al. Ultrastructure of the human intervertebral disc. I. Changes in notochordal cells with age. Tissue Cell 1982;14(2):359-369

143. Urban JPG, Roberts S. Degeneration of the intervertebral disc. Arthritis Research \& Therapy. 2003;5(3):120-130

144. Urban JPG, Smith S, Fairbank JC. Nutrition of the intervertebral disc. Spine (Phila Pa 1976) 2004;29:2700-2709

145. van den Eerenbeemt KD, Ostelo RW, van Royen BJ, et al. Total disc replacement surgery for symptomatic degenerative lumbar disc disease: a systematic review of the literature. Eur Spine J 2010;19:1262-1280

146. Vernon-Roberts B. Pirie CJ. Degenerative changes in the intervertebral discs of the lumbar spine and their sequelae. Rheumatol Rehabil 1977;16:13-21

147. Wang F, Wu XT, Zhuang SY, et al. Ex Vivo Observation of Human Nucleus Pulposus Chondrocytes Isolated From Degeneratedd Intervertebral Discs. Asian Spine Journal 2011;5(2):73-81. 
148. Wang GL, Jiang BH, Rue EA, et al. Hypoxia-inducible factor 1 is a basic-helix-loop-helixPAS heterodimer regulated by cellular O2 tension. Proc Natl Acad Sci USA 1995;92:5510-5514

149. Watanabe T, Sakai D, Yamamoto Y, et all. Human nucleus pulposus cells significantly enhanced biological properties in a coculture system with direct cell-to-cell contact with autologous mesenchymal stem cells. J Orthop Res 2010;28(5):623-30.

150. Weiler C, Nerlich AG, Schaaf R, et al. Immunohistochemical identification of notochordal markers in cells in the aging human lumbar intervertebral disc. Eur Spine J 2010;19:1761-1770

151. Weiler C, Nerlich AG, Zipperer J, et al. 2007 SSE Award Competition in Basic Science: expression of major matrix metalloproteinases is associated with intervertebral disc degeneration and resorption. Eur Spine J 2002;11(4):308-20

152. Welford SM, Giaccia AJ. Hypoxia and senescence: the impact of oxygenation on tumor suppression. Mol Cancer Res 2011;9(5):538-44

153. Yasuma T, Koh S, Okamura T, Yamauchi Y. Histological changes in aging lumbar intervertebral discs. J Bone Jt Surg 1990;72-A:220-229

154. Yoshimura H, Muneta T, Nimura A, et al. Comparison of rat mesenchymal stem cells derived from bone marrow, synovium, periosteum, adipose tissue, and muscle. Cell Tissue Res 2007;327:449-62

155. Zhang Y, Phillips FM, Thonar EJ, et al. Cell therapy using articular chondrocytes overexpressing BMP-7 or BMP-10 in a rabbit disc organ culture model. Spine (Phila PA 1976) 2008;33(8):831-8

156. Zhao CQ, Jiang LS, Dai LY. Programmed cell death in intervertebral disc degeneration. Apoptosis 2006;11:2079-2088

157. Zimmermann T, Kunisch E, Pfeiffer R, et al. Isolation and characterization of rheumatoid arthritis synovial fibroblasts from primary culture-primary culture cells markedly differ from fourth-passage cells. Arthritis Res 2001;3:72-76 


\section{Appendix A. Publications}

\section{Peer Reviewed Journal Publications}

1. Shoukry M, Pei M. Targeting an in vitro "niche" to facilitate cell-based nucleus pulposus regeneration. (Accepted)

2. Pei M, Shoukry M, Li J, Daffner SD, France JC, Emery SE. "Modulation of In Vitro Microenvironment Facilitates Synovium-Derived Stem Cell-Based Nucleus Pulposus Tissue Regeneration.” Spine 2012;37(18):1-10

3. William G, Shoukry M, Prucz J. "Analysis of Lightweighting Design Alternatives for Automotive Components ." SAE Technical Papers 2011: doi:10.4271/2011-01-2287

4. Pei M, Li JT, Shoukry M, Zhang Y. "A review of decellularized stem cell matrix: a novel cell expansion system for cartilage tissue engineering." European Cells and Materials 2011;22:333343

5. Pei M, Yan Z, Shoukry M, Boyce BM. "Failure of xenoimplantation using procine synoviumderived stem cell based cartilage tissue constructs for the repair of osteochondral defects." Journal of Orthopaedic Research 2010;28(8):1064-1070 (Journal Cover)

\section{Peer Reviewed Paper Presentations}

William G, Shoukry M, Prucz J. "Analysis of Lightweighting Design Alternatives for Automotive Components." Commercial Vehicle Engineering Congress, September 2011

\section{Poster Presentations}

Pei M, Shoukry M, Li J. "Modulation of an in vitro tissue-specific microenvironment to facilitate nucleus pulposus tissue regeneration." Poster presented as part of the Orthopoaedic Research Society Meeting, San Francisco, Calif., 4-7 February 4-7 2012 